\title{
AVALIAÇÃO DE DIFERENTES FONTES DE NITROGÊNIO EM EXPLANTES DE Cryptomeria japonica D. DON. "ELEGANS" CULTIVADOS IN VITRO: ANÁLISES BIOQUÍMICAS E RELAÇÕES ENTRE REGULADORES VEGETAIS
}

\author{
FLÁVIA REGINA CAPALDI
}

Dissertação apresentada à Escola Superior de Agricultura "Luiz de Queiroz", Universidade de São Paulo, para obtenção do título de Mestre em Recursos Florestais, Área de Concentração: Recursos Florestais, com opção em Manejo de Florestas de Produção.

PIRACICABA

Estado de São Paulo - Brasil

Fevereiro - 2002 


\section{AVALIAÇÃO DE DIFERENTES FONTES DE NITROGÊNIO EM EXPLANTES DE Cryptomeria japonica D. DON. "ELEGANS" CULTIVADOS IN VITRO: ANÁLISES BIOQUÍMICAS E RELAÇÕES ENTRE REGULADORES VEGETAIS}

\section{FLÁVIA REGINA CAPALDI}

Engenheiro Agrônomo

Orientador: Prof. Dr. ANTONIO NATAL GONÇALVES

Dissertação apresentada à Escola Superior de Agricultura "Luiz de Queiroz", Universidade de São Paulo, para obtenção do título de Mestre em Recursos Florestais, Área de Concentração: Recursos Florestais, com opção em Manejo de Florestas de Produção.

PIRACICABA

Estado de São Paulo - Brasil

Fevereiro - 2002 
Dados Internacionais de Catalogação na Publicação (CIP) DIVISÃO DE BIBLIOTECA E DOCUMENTAÇÃO - ESALQ/USP

\author{
Capaldi, Flávia Regina \\ Avaliação de diferentes fontes de nitrogênio em explantes de Crytomeria \\ japonica D. Don. "Elegans" cultivados 'in vitro' : avaliações bioquímicas e relações \\ entre reguladores vegetais / Flávia Regina Capaldi. - - Piracicaba, 2002. \\ $65 \mathrm{p}$. \\ Dissertação (mestrado) - - Escola Superior de Agricultura Luiz de Queiroz, \\ 2002. \\ Bibliografia. \\ 1. Bioquímica vegetal 2. Coníferas 3. Cultura de tecidos vegetais 4. Plantas \\ cultivadas (Fisiologia) 5. Propagação vegetal 6 . Reguladores vegetal I . Título
}

CDD 634.975

"Permitida a cópia total ou parcial deste documento, desde que citada a fonte - $O$ autor" 
"O que você pode fazer, ou sonharque pode, acontece. A determinação tem genialidade, força e magia." Goethe 


\section{AGRADECIMENTOS}

- A Deus, presença incondicional em todos os momentos.

- Ao Prof. Dr. Antonio Natal Gonçalves pela orientação, pela confiança, por seus ensinamentos e por sua amizade.

- À minha família, Sergio (in memorian) Inês, Sandra e Marco, pelo apoio, estímulo e paciência.

- À Escola Superior de Agricultura "Luiz de Queiroz" (ESALQ/USP) e ao Depto. de Ciências Florestais, pela estrutura fornecida para o desenvolvimento deste trabalho.

- À Fundação de Amparo à Pesquisa do Estado de São Paulo (FAPESP) pela concessão de bolsa de Mestrado e confiança no projeto de pesquisa.

- Ao Conselho Nacional de Pesquisa (CNPq) pela concessão de bolsa de Mestrado e confiança no projeto de pesquisa.

- Àos Prof. Drs. Adriana P. Martinelli Rodriguez (CENA/USP), João Alexio Scarpare Filho (LPV-ESALQ/USP) e Marcílio de Almeida (LCB-ESALQ/USP), pela importante colaboração e pelas valiosas sugestões fornecidas.

- Ao Prof. Dr. Paulo Y. Kageyama (LCF-ESALQ/USP) e à equipe do LARGEA, pelo auxílio prestado, em especial à Elza M. Ferraz. 
- Ao Prof. Dr. Flávio Tavares e sua equipe (LGN-ESALQ/USP): Alessandra, Polé, Felipe, Jupará, Keila, Ana e, em especial ao Dr. Luiz Humberto Gomes "Beto", pelo auxílio prestado durante os experimentos de Eletroforese.

- À Eng. Ftal. Sandra C. Capaldi Arruda, pelo valioso auxílio prestado em todo o desenvolvimento do trabalho.

- Aos amigos do LAFISA (LCF-ESALQ/USP): Ana Uliana, Beatriz de Matteo, Fábio da Silva, Gustavo Souza, João Sacchi, Juliana Viana, Marília Cantarelli, pela importante colaboração e pela agradável convivência, em especial ao Vanderlei Stefanuto.

- Ao técnico do LAFISA José Roberto Romanini, pelo auxílio prestado.

- Aos funcionários do Depto. de Ciências Florestais (ESALQ/USP): Maria de Fátima D. Juliane, Margarete Ap. Z. Pinese, Alexandre H. Najm e Danilo F. Pereira, pela incansável colaboração em todos os momentos requisitados.

- Ao Ivo Rosa Fiho, Rogério O. Naressi e Jeferson Polizel, pela amizade e auxílio nos serviços de Informática.

- Às bibliotecárias da BC-ESALQ/USP, Silvia Zinsly e Eliana Garcia, pelas correções realizadas.

- Aos Eng. Florestais Fábio Sgarbi, Mário Jorge C. dos Santos, Lúcia H. Menegon Basso e à Eng. Agr ${ }^{\circ}$. Daniela T. Stuchi Leite pela amizade e apoio. 


\section{Ofereço e Dedico...}

Aos meus pais Inêse Sergio (in memorian)

Exemplos de vida, de honestidade, de carátere de bondade.

Muito obrigada pela confiança, pelo apoio e pelo estímulo. 


\section{SUMÁRIO}

Página

LISTA DE ABREVIATURAS …………………............................ ix

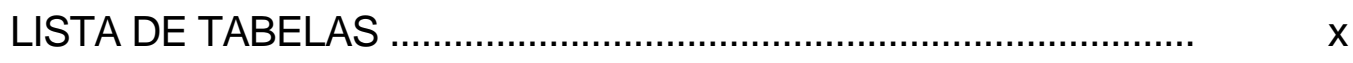

LISTA DE FIGURAS …................................................................

RESUMO ……................................................................ xiv

SUMMARY ............................................................................. Xvi

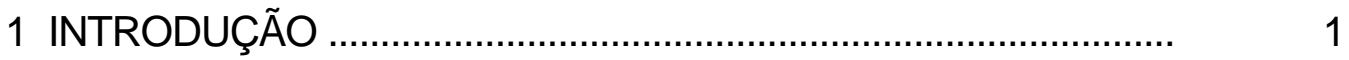

2 REVISÃO DE LITERATURA ......................................................

2.1 Nitrogênio, Nitrato e Amônio em cultivos 'in vitro' .......................... 4

2.1.1 O Nitrogênio nas Plantas e alguns aspectos Bioquímicos ......... 10

2.1.1.1 Aminoácidos e Proteínas ................................................... 12

2.1.1.2 Carboidratos ................................................................ 13

2.2 Uso de Reguladores Vegetais em cultivos 'in vitro' ..................... 14

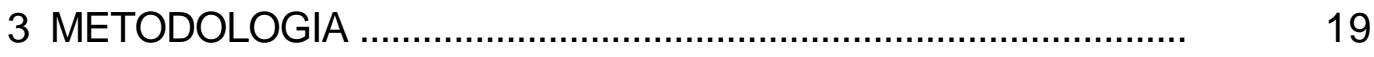

3.1 Metodologia Geral ............................................................... 19

3.1.1 Introdução dos explantes 'in vitro' .......................................... 19

3.2 Concentrações de nitrogênio utilizadas e instalação do experimento 20

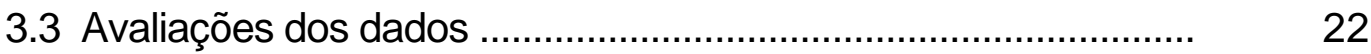

3.3.1 Determinação da massa vegetal seca ...................................... 22

3.3.2 Análise da taxa de crescimento relativo (TCR) ......................... 22 
3.3.3 Quantificação de proteínas solúveis totais (Bradford, 1976) .... 23

3.3.3.1 Extração de proteínas solúveis totais ...................................... 23

3.3.3.2 Quantificação de proteínas totais .......................................... 23

3.3.4 Eletroforese de Proteínas Solúveis Totais em gel de Poliacrilamida (Alfenas et al., 1991) ................................................. 24

3.3.5 Determinação de carboidratos não-estruturais totais pelo método

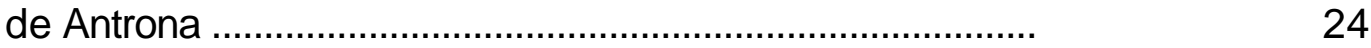

3.3.5.1 Extração dos carboidratos não-estruturais totais .................... 24

3.3.5.2 Determinação com reagente de Antrona .............................. 25

3.3.6 Determinação de aminoácidos solúveis totais (Passos, 1996) ... 25

3.3.6.1 Extração de aminoácidos solúveis totais ............................... 25

3.3.6.2 Determinação quantitativa .................................................. 26

3.4 Experimento com Reguladores Vegetais ..................................... 27

3.5 Análise Estatística dos Dados ......................................................... 28

3.6 Análise das bandas protéicas expressas no Gel ......................... 28

4 RESULTADOS E DISCUSSÃO ………………………................. 29

4.1 Análise da Taxa de Crescimento Relativo (TCR) e Incremento em massa vegetal seca ................................................................... 29

4.2 Conteúdos de Proteínas Solúveis Totais ................................... 36

4.3 Eletroforese de Proteínas Solúveis Totais .................................. 38

4.4 Conteúdos de Aminoácidos Solúveis Totais ............................... 40

4.5 Conteúdos de Carboidratos não estruturais Totais ....................... 44

4.6 Experimento com Reguladores Vegetais .................................... 47

4.6.1 Produção de Brotações ........................................................... 47

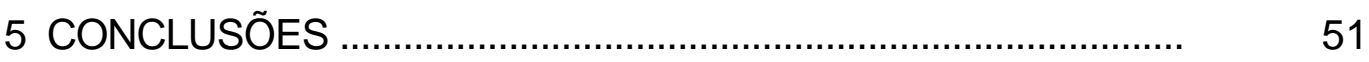

REFERÊNCIAS BIBLIOGRÁFICAS ............................................... 53

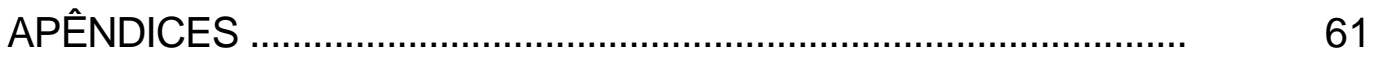




\section{LISTA DE ABREVIATURAS}

$\begin{array}{ll}\text { AIA } & \text { Ácido indol-3-acético } \\ \text { AIB } & \text { Ácido indol-butírico } \\ \text { ANA } & \text { Ácido } \alpha \text {-naftaleno acético } \\ \mathrm{BA} & \text { Benziladenina } \\ \mathrm{BAP} & \text { Benzilaminopurina } \\ \mathrm{BSA} & \text { Bovine Serum Albumine (Albumina Bovina) } \\ \mathrm{DMSO} & \text { Dimetil-sulfóxido } \\ \mathrm{KNO}_{3} & \text { Nitrato de potássio } \\ \mathrm{MS} & \text { Meio de cultura descrito por Murashigue \& Skoog (1962) } \\ \mathrm{N}^{-} & \text {Nitrogênio } \\ \mathrm{NH}_{4}{ }^{+} & \text {Amônio } \\ \mathrm{NH}_{4} \mathrm{NO}_{3} & \text { Nitrato de amônio } \\ \mathrm{NO}_{3}{ }^{-} & \text {Nitrato } \\ \mathrm{PAGE} & \text { Polyacrylamide gel Electrophoresis (Eletroforese em gel de } \\ \mathrm{PVP}_{\mathrm{rpm}} & \text { poliacrilamida) } \\ \mathrm{SDS} & \text { Polivinilpirrolidona } \\ \mathrm{TEMED} & \text { Rotações por minuto } \\ & \text { Dodecil-sulfato de sódio } \\ \end{array}$




\section{LISTA DE TABELAS}

Página

1 Relações nitrato:amônio utilizadas nos tratamentos ... 20

2 Relações ANA:BAP utilizadas no experimento com

Reguladores Vegetais ............................................... 27 


\section{LISTA DE FIGURAS}

Página

1 Taxa de Crescimento Relativo (TCR) dos explantes de Cryptomeria japonica D. Don "elegans" cultivados 'in vitro' sob diferentes concentrações de $\mathrm{NO}_{3}{ }^{-}$e $\mathrm{NH}_{4}{ }^{+}$(Tabela 1). Análise de comparação de médias realizada segundo a legenda. As barras que contém as mesmas letras não apresentaram diferenças significativas segundo o Teste de Tukey $(p<0,05)$..

2 Explantes de Cryptomeria japonica D. Don "elegans" mantidos em meio de cultura MS ( $\mathrm{T} 1=$ controle) após 90 dias de cultivo 'in vitro'. Nota-se a formação de pequenos calos, porém a formação de gemas foi baixa e menor do que a observada em outros tratamentos analisados. Nota-se também a formação de raiz, porém este evento foi de ocorrência esporádica

3 Explantes de Cryptomeria japonica D. Don. "elegans" aos 90 dias de cultivo 'in vitro', sob os tratamentos: (a) T4: $25 \mathrm{mmol}^{-\mathrm{L}^{-1}}$ de $\mathrm{NO}_{3}^{-}+5 \mathrm{mmol}^{-} \mathrm{L}^{-1}$ de $\mathrm{NH}_{4}^{+}\left(30 \mathrm{mmol}^{-1}\right.$ de N) e (b) T5: 22,5mmol. $\mathrm{L}^{-1}$ de $\mathrm{NO}_{3}{ }^{-}$e $2,5 \mathrm{mmol} . \mathrm{L}^{-1}$ de $\mathrm{NH}_{4}{ }^{+}\left(25 \mathrm{mmol} . \mathrm{L}^{-1}\right.$ de N$)$. Tanto em T4 como em T5 nota-se a formação de calos e brotações em maior quantidade que em $\mathrm{T} 1$ 
4 Explantes de Cryptomeria japonica D. Don. "elegans" aos 90 dias de cultivo 'in vitro', sob os tratamentos: (a) T8 (31 mmol. $\mathrm{L}^{-1}$ de $\mathrm{NO}_{3}{ }^{-}+5 \mathrm{mmol} . \mathrm{L}^{-1}$ de $\mathrm{NH}_{4}{ }^{+}$), onde observou-se a formação de calos, brotações e pequenas raízes e (b) T10 $\left(26 \mathrm{mmol}^{-L^{-1}}\right.$ de nitrato), onde nota-se a intensa formação de calos, brotações e raízes

5 Incremento médio em massa vegetal seca $(\mathrm{mg})$ por subcultivo analisado (1, 2 e 3 correspondendo a 30, 60 e 90 dias respectivamente) em explantes de Cryptomeria japonica D. Don. "elegans" cultivados 'in vitro' sob diferentes concentrações de nitrato e amônio. O T1 refere-se ao meio de cultura MS, considerado como controle .................................... 33

$6 \quad$ Curva Analítica de Calibração para albumina ............................ 36

7 Conteúdos de proteínas solúveis totais encontrados ao final de 90 dias de cultivo 'in vitro' de explantes de Cryptomeria japonica D. Don. "elegans" mantidos sob as diferentes concentrações de $\mathrm{NO}_{3}{ }^{-}$e $\mathrm{NH}_{4}{ }^{+}$propostas (Tabela 1). As barras que apresentam as mesmas letras referem-se aos tratamentos que não diferiram significativamente entre si, conforme o Teste de Tukey, para $\mathrm{p}<0,05$

8 Bandas protéicas observadas em explantes de Cryptomeria japonica D. Don. "elegans” após 90 dias de cultivo 'in vitro' sob os tratamentos com diferentes concentrações de $\mathrm{NO}_{3}{ }^{-}$e $\mathrm{NH}_{4}{ }^{+}$, indicados por Tx (Tabela 1). O padrão de proteínas utilizado está representado pela letra $\mathbf{P}$ e os valores numéricos contidos na figura representam os pesos moleculares das proteínas 
constituintes do padrão, em $\mathrm{KDa}$. As setas indicam: (a) expressão de bandas protéicas que não foi observada no controle e (b) diferença na intensidade de expressão das bandas quando comparadas ao controle

9 Curva Analítica de Calibração para Leucina

10 Teores de aminoácidos solúveis totais quantificados nos explantes de Cryptomeria japonica D. Don. ao final de 90 dias de cultivo 'in vitro', sob as diferentes concentrações de $\mathrm{NO}_{3}{ }^{-} \mathrm{e}$ $\mathrm{NH}_{4}{ }^{+}$propostas (Tabela 1). As barras que exibem as mesmas letras referem-se aos tratamentos que não diferiram significativamente entre si, segundo o Teste de Tukey, para $\mathrm{p}<0,05$

11 Curva Analítica de Calibração para Glicose

12 Conteúdos de carboidratos não-estruturais totais ao final de 90 dias no explantes de Cryptomeria japonica D. Don. "elegans" cultivados 'in vitro' sob diferentes concentrações de $\mathrm{NO}_{3}{ }^{-}$e $\mathrm{NH}_{4}{ }^{+}$ (Tabela 1). As barras com as mesmas letras referem-se aos tratamentos que não apontam diferenças significativas quanto ao Teste de Tukey, para $p<0,05$

13 Número médio de brotações formadas por explante e altura média $(\mathrm{mm})$ das brotações produzidas em 3 subcultivos (90 dias). Resultados obtidos a partir de explantes de Cryptomeria japonica D. Don. "elegans" cultivados 'in vitro' nos diferentes meios de cultura determinados por $\boldsymbol{T} \boldsymbol{x}$ e suplementados por diferentes concentrações de ANA e BAP (Tabela 2). As colunas com as mesmas letras não diferiram entre si conforme o Teste de Tukey, para $p<0.05$ 


\title{
AVALIAÇÃO DE DIFERENTES FONTES DE NITROGÊNIO EM EXPLANTES DE CRYPTOMERIA JAPONICA D. DON. "ELEGANS" CULTIVADOS 'IN VITRO': AVALIAÇÕES BIOQUÍMICAS E RELAÇÕES ENTRE REGULADORES VEGETAIS
}

\author{
Autora: FLÁVIA REGINA CAPALDI \\ Orientador: Prof. Dr. ANTONIO NATAL GONÇALVES
}

\section{RESUMO}

A Cryptomeria japonica D. Don. "elegans" é uma conífera pertencente à família Taxodiaceae, que apresenta crescimento rápido e boas respostas à fertilização. Dez variações nas concentrações de nitrato e amônio presentes no meio de cultura MS foram realizadas no cultivo 'in vitro'de brotações obtidas a partir de explantes primários de ápices caulinares durante 90 dias. A cada 30 dias foram avaliados, a taxa de crescimento relativo e o incremento em massa vegetal seca. Ao final de 90 dias, foram realizadas análises dos teores de proteínas solúveis totais, aminoácidos solúveis totais, carboidratos nãoestruturais totais e eletroforese de proteínas totais em gel de poliacrilamida. Os tratamentos que exibiram resultados mais satisfatórios foram utilizados em um experimento com diferentes relações auxina/citocinina, onde foram avaliadas a produção de brotações e a altura média das mesmas aos 30,60 e 90 dias de cultivo. As concentrações de nitrato e amônio entre 25 e $31 \mathrm{mmol}^{-1} \mathrm{~L}^{-1}$ e até 
$5 \mathrm{mmol} \mathrm{L}^{-1}$, respectivamente, foram as mais efetivas para o crescimento $\mathrm{e}$ desenvolvimento do material vegetal cultivado 'in vitro'. Durante o experimento com diferentes concentrações de ANA e BAP, foi possível observar que a produção de brotações, etapa essecial para um processo de micropropagação eficiente, foi superior quando as combinações entre nitrato e amônio foram 22,5 + $2,5 \mathrm{mmol} . \mathrm{L}^{-1}$ e $25,0+5,0 \mathrm{mmol} . \mathrm{L}^{-1}$. 


\title{
EVALUATION OF THE DIFFERENT NITRATE AND AMMONIUM CONCENTRATIONS IN EXPLANTS OF Cryptomeria japonica D. DON. “ELEGANS” CULTIVATED 'IN VITRO'
}

\author{
Author: FLÁVIA REGINA CAPALDI \\ Adviser: Prof. Dr. ANTONIO NATAL GONÇALVES
}

\section{SUMMARY}

Cryptomeria japonica D. Don. "elegans" is a fast-growing tree belonging to the Taxodiaceae and it is considered a responsive species 'in vitro'. The aim of this work was to evaluate the effect of ten different concentrations of nitrate and ammonium in morphogenesis 'in vitro' of Cryptomeria japonica D. Don. "elegans" explants. Analysis of relative growth rate, total soluble proteins, total soluble aminoacids, total non structural carbohydrates and electrophoresis of total proteins was performed in order to observe the role of different nitrogen sources on the growth and development of the explants cultivated 'in vitro'. The concentratios of nitrate and ammonium that showed the best results were selected and used in an experiment with different concentrations of NAA and BAP to observe the shoot production. Each experiment was analised at the $30^{\text {th }}, 60^{\text {th }}$ and $90^{\text {th }}$ days of culture. The biochemical analysis was performed only at $90^{\text {th }}$ day of cultive. Concentrations from 26 to $31 \mathrm{mmol}^{-1}$ of $\mathrm{NO}_{3}^{-}$and lower than $5 \mathrm{mmol} . \mathrm{L}^{-1}$ of $\mathrm{NH}_{4}{ }^{+}$were the most effective for growth and development of the 
explants. However, the experiment with different concentrations of NNA and BAP showed that the best shoot production was achieved on $22,5 \mathrm{mmol}^{-\mathrm{L}^{-1}}$ of $\mathrm{NO}_{3}{ }^{-}+2,5 \mathrm{mmol} . \mathrm{L}^{-1}$ of $\mathrm{NH}_{4}{ }^{+}$and on $25,0 \mathrm{mmol} . \mathrm{L}^{-1}$ of $\mathrm{NO}_{3}{ }^{-}+5,0 \mathrm{mmol} \cdot \mathrm{L}^{-1}$ of $\mathrm{NH}_{4}{ }^{+}$and with $2,0 \mathrm{mg} \cdot \mathrm{L}^{-1}$ of BAP $+1,0 \mathrm{mg} \cdot \mathrm{L}^{-1}$ of NNA. 


\section{INTRODUÇÃO}

A cultura de tecidos constitui-se num processo altamente flexível à propagação de plantas, pois vem se obtendo sucesso nos resultados conforme o tipo de material vegetal utilizado como explante, em combinação com a técnica de cultivo mais apropriada e o objetivo estabelecido. Também devem ser considerados os diferentes comportamentos dos materiais vegetais na presença de composições variadas de meios de cultura, tipos e concentrações de fitorreguladores, entre outros fatores, os quais influenciam os processos vitais do crescimento e do desenvolvimento vegetal.

Nos diversos processos da cultura de tecidos, a morfogênese é extremamente influenciada pela disponibilidade e pela forma de suprimento de nitrogênio no meio de cultura. Assim como a produção de brotações é influenciada pela relação auxina/citocinina fornecida aos explantes.

A composição química adequada de um meio de cultura é um dos aspectos mais importantes na micropropagação em geral, pelo fato de influenciar diretamente no processo de morfogênese e também por ser o fator de mais fácil manipulação no processo de micropropagação. A escolha do meio de cultura mais adequado para determinada técnica e fase da micropropagação influenciará diretamente na otimização do processo para um determinado genótipo (Teasdale, 1987).

A comparação entre nitrato e amônio é de grande importância e a literatura aponta diversos trabalhos realizados com plantas cultivadas 'in vitro' e 'in vivo'. Essa importância é devida ao incremento no uso de fertilizantes em cultivos florestais e também, pelo fato de algumas espécies responderem bem à 
presença de amônio no meio de cultivo, enquanto que, para outras espécies, é um íon que provoca toxicidade, afetando o crescimento das plantas.

O nitrogênio é um nutriente de essencialidade incontestável dentro de qualquer fase do desenvolvimento vegetal e uma de suas funções é a formação de compostos básicos ao ciclo de vida vegetal (aminoácidos, proteínas, ácidos nucléicos, entre outros). Considerando esse fato e, associando às informações obtidas na literatura a respeito do comportamento das plantas, especialmente coníferas, sob diferentes fontes de N, algumas hipóteses foram determinadas para o desenvolvimento dessa dissertação: (a) o nitrogênio desempenha papel fundamental na multiplicação 'in vitro' de gemas e no processo de crescimento das plantas e, as relações entre as fontes de $\mathrm{N}$ fornecidas ao meio de cultura proporcionam respostas morfogênicas variadas durante o cultivo 'in vitro'; (b) o balanço nitrato:amônio pode alterar o teor protéico, a síntese de aminoácidos e o teor de carboidratos totais do material vegetal em estudo e (c) as relações entre a auxina e a citocinina são responsáveis por respostas morfogênicas diferenciadas nos explantes cultivados 'in vitro'.

A escolha do material vegetal utilizado para o desenvolvimento dos estudos propostos nessa dissertação partiu do princípio de que seria desejável optar-se por uma espécie de conífera, conforme informações obtidas na literatura sobre o seu comportamento sob diferentes regimes de fornecimento de $\mathrm{N}$ (fontes e concentrações). Apesar de não ser uma espécie altamente difundida e cultivada como as espécies do gênero Eucalyptus e Pinus, a Cryptomeria japonica D. Don. "elegans" foi considerada propícia, por apresentar crescimento rápido em comparação a outras espécies de coníferas e boa resposta à fertilização, ou seja, é possível obter respostas significativas e num período de tempo satisfatório.

Em relação às características mais comerciais da espécie, podemos citar a qualidade da sua madeira, que é leve, porém densa, de coloração avermelhada e, por isso, altamente valorizada em países como Estados Unidos, Japão e alguns países europeus. As principais finalidades do uso da madeira 
da Cryptomeria japonica são para confecção de móveis, pisos e casas. Já a árvore é utilizada para fins ornamentais, paisagísticos, reflorestamento e cerca viva. Em sua fase juvenil, é comercializada como árvore de Natal. Sua característica de planta medicinal também é apontada na literatura, assim como o seu cultivo para a extração de óleos essenciais, para uso na indústria farmacêutica.

No Brasil, as principais finalidades para o seu cultivo são o uso ornamental, paisagístico e para reflorestamento, sobretudo em regiões com climas mais amenos.

O objetivo deste trabalho foi avaliar o efeito de diferentes concentrações de nitrato e amônio no cultivo 'in vitro' de explantes de Cryptomeria japonica D. Don. "elegans".

Para que esse objetivo fosse atingido, etapas específicas foram consideradas: avaliações de crescimento relativo dos explantes, formação de calos e brotações e, análises bioquímicas de proteínas solúveis totais, aminoácidos solúveis totais e carboidratos não estruturais totais, como indicadores de um processo adequado de organogênese. Para auxiliar a análise das proteínas, foi também utilizada a técnica de eletroforese em gel de poliacrilamida (SDS-PAGE).

A partir destas avaliações, foram selecionadas as concentrações de nitrato e amônio que exibiram resultados mais satisfatórios, as quais foram utilizadas em um estudo com reguladores vegetais, visando observar a capacidade de formação de calos e brotações sob tais concentrações de nitrato e amônio e sob diferentes relações entre auxina e citocinina. 


\section{REVISÃO DE LITERATURA}

\subsection{Nitrogênio, Amônio e Nitrato em cultivos 'in vitro'}

A biotecnologia oferece várias possibilidades para as pesquisas e a propagação clonal tem sido considerada como a principal via para o presente. (Toribio et al., 1989).

O aumento do interesse no uso das técnicas de cultura de tecidos de plantas está documentado na literatura recente, abrangendo os mais variados aspectos da agricultura, horticultura, florestas e da indústria farmacêutica (Pochet et al., 1991).

O cultivo 'in vitro' de Pinus sylvestris tem sido realizado em várias composições de meios de cultura. Entretanto, para obter o crescimento ótimo e a morfogênese da espécie é necessário estabelecer-se uma composição própria de meio de cultura. As proporções dos diferentes nutrientes presentes no meio de cultura são de grande importância, pois segundo a teoria de Ingestad (1979), a absorção de cada nutriente influencia e é influenciada pelos outros (Toribio et al., 1989).

Ingestad (1992) realizou experimentos com explantes de $P$. sylvestris cultivados 'in vitro' em diferentes meios de cultura durante 90 dias, testando a concentração de nitrogênio total e também a relação amônio:nitrato presente em cada composição, sendo a maior concentração de nitrogênio total aquela que se encontra no meio de cultura MS $\left(60 \mathrm{mmol}^{-1} \mathrm{~L}^{-1}\right.$ de $\mathrm{N}$ total e relação amônio:nitrato de 
1:2). Os resultados mostram que a absorção de amônio pelos explantes foi melhor que a absorção de nitrato conforme a relação entre os dois íons. Os resultados indicam ainda que altos níveis de amônio presentes no meio de cultura causaram perda do potencial morfogenético dos explantes. Foi desenvolvida uma composição de meio de cultura baseada nos teores descritos por Ingestad (1979) a qual foi comparada com outros meios de cultura mais utilizados na propagação 'in vitro' de coníferas: o MS (Murashigue \& Skoog, 1962), o SH (Schenk \& Hildebrandt, 1972) e o S (Sommer et al, 1975). Os resultados mostram que o incremento de peso fresco e número de gemas foi melhor nos meios $\mathrm{SH}$ (27mmol.L $\mathrm{L}^{-1}$ de $\mathrm{N}$ total e relação amônio:nitrato de 1:9) e $\mathrm{S}\left(13 \mathrm{mmol} . \mathrm{L}^{-1}\right.$ de $\mathrm{N}$ total e relação amônio:nitrato de aproximadamente 1:3,5). O meio MS mostrou-se prejudicial ao desenvolvimento dos explantes após a análise de 3 subcultivos (90 dias), o que foi atribuído à presença de alta quantidade de nitrogênio total no meio de cultura.

Muitos meios de cultura, usados no cultivo 'in vitro' de espécies florestais, contém tanto nitrato como amônio. Os íons $\mathrm{NH}_{4}{ }^{+}$podem ser incorporados aos aminoácidos sem a necessidade do processo de redução, assim como suprimentos externos de aminoácidos podem ser incorporados diretamente aos processos de biossíntese. A absorção das formas reduzidas de $\mathrm{N}$ também estimula a atividade da nitrato-redutase, facilitando o metabolismo do nitrato (George et al. ${ }^{1}$, citado por GROSSI, 1995).

Segundo Elkonin et al (2000), a composição do meio de cultura é um dos fatores chave que afetam a morfogênese em células cultivadas 'in vitro'. Os autores realizaram experimentos a partir de explantes de panículas de sorgo (Sorghum bicolor) cultivadas 'in vitro' sob diferentes balanços nitrato:amônio e também usando fontes orgânicas de nitrogênio (prolina e aspargina) em meio de cultura MS modificado, concluindo que composições com diferentes níveis e fontes de nitrogênio afetam significativamente a intensidade de proliferação de 
calos embriogênicos dos explantes. O potencial regenerativo destes calos, entretanto, foi mais estimulado pela composição básica do MS suplementada por aspargina.

Os meios de cultura comumente usados para a cultura de tecidos vegetais apresentam diferentes concentrações de nitrogênio e na maioria dos casos, o fornecimento de nitrogênio é inorgânico pela combinação de nitrato e amônio. A concentração de nitrogênio total entre os meios mais usados varia entre 14,7mmol. $\mathrm{L}^{-1}$ (WPM, Lloyd e McCown) a 60,0 mmol.L $\mathrm{L}^{-1}$ (MS), com relações nitrato:amônio de 1,9;2,0;6,6;9,5 e 30,0. Comparações de respostas de crescimento e desenvolvimento de explantes cultivados nestes meios de cultura permitem algumas conclusões a respeito dos efeitos das diferenças quantitativas e qualitativas no conteúdo de nitrogênio fornecido aos explantes (Tsai et al., 1999).

A micropropagação de Thuja plicata foi obtida a partir de brotações axilares cultivadas em meio MS modificado e apresentando doses reduzidas da concentração de nitrato de amônio $\left(\mathrm{NH}_{4} \mathrm{NO}_{3}\right)$ para $1 / 4$ da concentração básica do meio de cultura. A dose de $\mathrm{KNO}_{3}$ permaneceu a mesma da composição original do meio de cultura MS. O experimento aponta que as concentrações reduzidas de nitrogênio total, nitrato e amônio, foram positivas a micropropagação de diferentes clones da espécie (Pochet et al, 1991).

Plantas de Picea abies e Pinus nigra apresentaram quantidades significativas de amônio em sua folhagem, sem exibir, entretanto, efeitos negativos em seu crescimento, sugerindo que algumas coníferas podem ser tolerantes à presença de amônio livre no simplasto (van den Driessche, 1991).

Uma desvantagem que tem sido atribuída à utilização de altas concentrações de amônio ou sua utilização como única fonte de $\mathrm{N}$ no meio de cultura, é a indução da vitrificação, principalmente para espécies arbóreas. Ao 
contrário, o suprimento de $\mathrm{N}$ em fontes reduzidas tem-se mostrado importante para a formação direta de gemas em algumas espécies (George, 1984).

Na micropropagação de Douglas-fir (Pseudotsuga menziesii), tem sido utilizado o meio MS à $1 / 2$ concentração e, também várias outras composições que apresentam concentrações de sais decrescentes a partir do MS básico, para promover o desenvolvimento e 0 alongamento de gemas e o enraizamento 'in vitro'. Embriões zigóticos desenvolveram-se melhor em meio de cultura MS à $1 / 4$ da concentração. Uma das razões atribuídas ao desenvolvimento superior dos explantes é a alteração do conteúdo de nitrogênio total no meio de cultura (Goldfarb et al, 1989).

Thompson et al. (1981) realizaram experimentos com diversas espécies arbóreas e concluíram que níveis reduzidos de $\mathrm{KNO}_{3}$ e $\mathrm{NH}_{4} \mathrm{NO}_{3}$ no meio de cultura (1/4 da concentração existente no MS, ou seja, $475 \mathrm{mg} \cdot \mathrm{L}^{-1} \mathrm{KNO}_{3} \mathrm{e}$ $412,5 \mathrm{mg} \cdot \mathrm{L}^{-1} \mathrm{NH}_{4} \mathrm{NO}_{3}$ ) foram essenciais à indução de gemas adventícias em explantes de árvores maduras.

Os efeitos dos íons $\mathrm{NH}_{4}{ }^{+}$e $\mathrm{NO}_{3}{ }^{-}$no crescimento de calos de Pinus strobus foram estudados. Os calos cultivados em meio de cultura MS tendo o $\mathrm{KNO}_{3}$ ou $\circ \mathrm{NH}_{4} \mathrm{NO}_{3}$ como única fonte de nitrogênio sobreviveram e foram mantidos em subcultivos. Entretanto, os calos cultivados em meio MS tendo o $\mathrm{NH}_{4} \mathrm{Cl}$ como única fonte de nitrogênio tiveram seu crescimento inibido pela presença do íon $\mathrm{NH}_{4}$. Porém, o efeito inibitório foi cancelado pela adição de quantidades ótimas de $\mathrm{KNO}_{3}$ ao meio de cultura MS que continha somente amônio. O efeito tóxico foi atribuído ao $\mathrm{NH}_{4}{ }^{+}$e não ao íon $\mathrm{Cl}$, pelo fato de que calos obtiveram bom crescimento quando cultivados em meio de cultura MS contendo $\mathrm{KCl}$. Os experimentos sugerem que o crescimento dos calos foi inibido pela inabilidade das plantas em usar o amônio como única fonte de nitrogênio, proporcionando o acúmulo de íons $\mathrm{NH}_{4}{ }^{+}$em níveis tóxicos em seus tecidos (Kaul et al., 1993). 
Segundo Bajaj (1989), concentrações baixas de amônio foram críticas para o crescimento normal e o desenvolvimento de embriões zigóticos 'in vitro'. O autor também indica que a forma específica do nitrogênio presente no meio de cultura pode afetar o sucesso da cultura. Enquanto que concentrações maiores de amônio podem diminuir ou inibir o crescimento dependendo da espécie cultivada.

Porter et al. (1991) indicam o meio de cultura SH como o mais indicado ao desenvolvimento de gemas em embriões, pela composição do meio apresentar teor reduzido de amônio.

Tremblay et al (1991) mostram que concentrações de nitrato de amônio $\left(\mathrm{NH}_{4} \mathrm{NO}_{3}\right.$ ) de 3,4 a $10,0 \mathrm{mmol}^{-1}$ (para Picea mariana) ou $15,0 \mathrm{mmol}^{-1}$ (para Picea rubens) não apresentaram efeitos na maturação de embriões somáticos (maduros e imaturos) das determinadas espécies, porém na concentração de $30 \mathrm{mmol}^{-\mathrm{L}^{-1}}$ exibiu efeito inibitório no desenvolvimento dos embriões para as duas espécies de coníferas. Neste experimento, portanto, os meios de cultura ausentes de nitrato de amônio foram considerados aptos ao suporte do desenvolvimento de embriões somáticos para as espécies testadas. $O$ peso fresco dos embriões de $P$. mariana decresceu nas concentrações citadas acima, porém só foi observada diminuição do peso fresco para $P$. rubens na dosagem de $30 \mathrm{mmol}^{-L^{-1}}$ de $\mathrm{NH}_{4} \mathrm{NO}_{3}$.

Vários autores têm discutido as interações entre a concentração de nitrogênio total e a relação entre as fontes disponíveis de nitrogênio presentes nos meios de cultivo e também o suprimento de nitrogênio com fontes orgânicas, como os aminoácidos (Bajaj, 1989).

Evers (1988) concluiu que a melhor relação $\mathrm{NH}_{4}{ }^{+} \mathrm{NO}_{3}{ }^{-}$igual a $1: 5$ foi a que proporcionou melhor resultado na indução de gemas num cultivo 'in vitro' de Alnus glutinosa. Já na fase de alongamento das gemas, a melhor relação foi a de 1:8. Em outro trabalho, o mesmo autor concluiu que, na fase inicial do cultivo 
de Salix alba, a melhor relação foi a presente na composição básica do MS (1962), $40 \mathrm{mmol}^{-\mathrm{L}^{-1}}$ de $\mathrm{NO}_{3}{ }^{-}$e $20 \mathrm{mmol}^{-\mathrm{L}^{-1}}$ de $\mathrm{NH}_{4}{ }^{+}$.

Veliky et al. (1973) cultivaram células de cenoura em suspensão em meio líquido contendo fontes inorgânicas ou orgânicas de nitrogênio e concluíram que os meios suplementados por fontes inorgânicas de $N$ exibiram um poder tampão maior que aqueles suplementados por caseína-hidrolisada. Os autores sugerem que a produção de biomassa foi controlada não somente pela utilização de amônio e nitrato, mas também pela concentração e pela relação entre as duas fontes. Também sugerem que as variáveis (amônio e nitrato) são as maiores responsáveis pela produção e incremento de peso seco das células, porém a resposta das células a estes fatores é complexa, pois os dados apresentam claramente, uma concentração em excesso de nitrato (em comparação aos meios usados) para a obtenção do crescimento ótimo em análise de peso seco. Os dados obtidos indicam que os mecanismos celulares de conversão de fontes inorgânicas de nitrogênio em orgânicas podem, sob certas condições, limitar a taxa e a eficiência de conversão de nutrientes em biomassa.

Tsai et al. (1999) realizaram estudos com fontes isoladas de nitrogênio no meio de cultura MS para o cultivo 'in vitro' de explantes de beterraba (Beta vulgaris), apontando que as concentrações de amônio e nitrato mais produtivas para a multiplicação de gemas foram, respectivamente, $70 \%\left(14 \mathrm{mmol}^{-1} \mathrm{~L}^{-1}\right)$ e $64 \%$ $\left(25,6 \mathrm{mmol}^{\mathrm{L}} \mathrm{L}^{-1}\right)$ do meio MS. Já para a formação de calos a partir de explantes de discos de folhas, o amônio fornecido isoladamente proporcionou respostas semelhantes às respostas encontradas com a composição básica do MS, ou seja, o fornecimento isolado de $20 \mathrm{mmol}^{-L^{-1}}$ de amônio foi responsável por uma resposta semelhante em relação ao meio MS na formação de calos, porém não houve formação de gemas. No caso da formação de calos, o nitrato foi efetivo na dose de $50 \%$ do $\mathrm{MS}$, ou seja, $20 \mathrm{mmol} . \mathrm{L}^{-1}$ de nitrato fornecido isoladamente e neste caso houve regeneração. 
O acúmulo de nitrogênio pelas plantas, em reposta ao suprimento e a capacidade de assimilação é um fenômeno comum a muitas espécies. Se o suprimento de uma forma particular de $\mathrm{N}$ resulta em maior absorção que a necessária para manter um crescimento ótimo, o acúmulo desta forma de $\mathrm{N}$ irá ocorrer (Millard, 1988).

Em cultivo 'in vivo' de "seedlings" de Pinus rigida foi detectado que o conteúdo total de $\mathrm{N}$ nas folhas analisadas foi influenciado pela fonte (amônio ou nitrato) usada. $\mathrm{O}$ incremento foliar de $\mathrm{N}$ foi atribuído ao aumento da disponibilidade de amônio na solução nutritiva em seedlings não inoculados com fungos micorrízicos. O nível de compostos orgânicos nas folhas também aumentou com o incremento de amônio à solução nutritiva (Cumming, 1990).

Laukkanen et al. (1997) estudaram o efeito de duas diferentes fontes de $\mathrm{N}$ em culturas de calos de Pinus sylvestris, em meio MS modificado e indicaram que o crescimento dos calos foi baixo no meio de cultura que continha somente nitrato, porém os calos cultivados neste tratamento, exibiram uma intensificação em seu metabolismo, principalmente em relação à síntese de proteínas e compostos fenólicos. Alterações nas bandas protéicas também foram notadas quando foi realizada a eletroforese em gel de poliacrilamida. Por outro lado, os calos que cresceram na presença de nitrato de amônio apresentaram desenvolvimento superior, porém padrões bioquímicos inferiores.

A influência da composição do meio de cultura no crescimento e na morfogênese de Picea sitchensis foi estudada por Selby et al. (1990), os quais indicaram que a maior produção de brotações adventícias ocorreu sob as relações amônio:nitrato iguais a 1:2 e 1:5.

\subsubsection{O Nitrogênio nas Plantas e alguns Aspectos Bioquímicos}

Entre os elementos principais à nutrição das plantas, o nitrogênio tem um grande significado. Como componente quantitativo da fitomassa, o $\mathrm{N}$ ocupa a 
quarta posição, após $\circ \mathrm{C}, \circ \mathrm{O}$ e $\circ \mathrm{H}$. A parte aérea das plantas herbáceas contém, em média, 2 a 4\% de nitrogênio; as folhas de árvores decíduas contém 1,5 a $3 \%$ de $\mathrm{N}$; as acículas e folhas esclerofilas contém entre 1 e $2 \%$ de $\mathrm{N}$, os ramos e raízes contém 0,5 a $1 \%$ de $\mathrm{N}$, as algas planctônicas apresentam de 5 a $8 \%$ de $\mathrm{N}$ e as proteínas apresentam entre 15 a 19\% de nitrogênio (Larcher, 2000).

Em ecossistemas florestais, o nitrato e o amônio são as fontes mais abundantes de nitrogênio disponíveis às raízes das plantas. O teor total de nitrato e amônio, assim como a relação entre as duas fontes depende da qualidade e da quantidade do nitrogênio adicionado e do balanço dos processos de amonificação, nitrificação, imobilização e denitrificação que ocorrem no solo. O nitrato é a fonte predominante nos solos com pH neutro e boa aeração, geralmente usados para agricultura, enquanto que o amônio desempenha importante papel em solos florestais. A importância do amônio como fonte de N para as árvores aumenta em regiões adjacentes às áreas com agricultura intensiva, onde as culturas florestais são expostas a um incremento de $\mathrm{NH}_{4}{ }^{+}$ proveniente da atmosfera (Gessler et al, 1998; Larcher, 2000).

A disponibilidade do nitrogênio inorgânico no solo é freqüentemente um fator limitante ao crescimento das plantas. O nitrato é a forma mais comumente usada pelas plantas, exceto em solos onde a nitrificação é baixa e o amônio predomina. Após a absorção pela célula, o nitrato é reduzido a amônio, antes de ser incorporado em compostos nitrogenados (Cánovas et al, 1998).

As plantas superiores, em geral, são capazes de absorver o $\mathrm{N}$ sob diferentes formas: $\mathrm{N}_{2}$ (gás, caso das leguminosas e outras espécies), aminoácidos, uréia, $\mathrm{NH}_{4}{ }^{+}$e predominantemente nas condições naturais e aeróbicas, como $\mathrm{NO}_{3}$. Ao absorver amônio, há aumento da acidez devido à saída de $\mathrm{H}^{+}$proveniente, por exemplo, da dissociação do $\mathrm{H}_{2} \mathrm{CO}_{3}$ respiratório. Havendo absorção de nitrato, diminui a acidez, pelo aparecimento de $\mathrm{OH}^{-}$, originário da sua redução: $\mathrm{NH}_{3}{ }^{-}+8 \mathrm{H} \rightarrow \mathrm{NH}_{3}+\mathrm{H}_{2} \mathrm{O}+\mathrm{OH}^{-}$(Malavolta, 1997). 
O nitrogênio é transportado no xilema e redistribuído principalmente no floema, em processos relativamente rápidos. $\mathrm{Na}$ planta, quase todo o $\mathrm{N}$ se encontra em formas orgânicas representadas em maior proporção por aminoácidos e proteínas (Malavolta, 1997).

O amônio e o nitrato são dois dos íons mais rapidamente acumulados, formando compostos rapidamente. O amônio é tóxico a um grande número de espécies e seu acúmulo pode resultar comprometimento do crescimento das plantas. Entretanto, algumas coníferas têm demonstrado bom crescimento na presença de amônio, sendo que em muitos casos, a espécie apresenta melhor desenvolvimento na presença de um suprimento combinado entre amônio e nitrato (van den Driessche, 1991).

As curvas de absorção relativas de nitrato e amônio são dependentes da espécie e do pH. Uma grande fração do amônio e do nitrato acumulados é incorporada em compostos orgânicos na raiz e, posteriormente translocados à parte aérea da planta na forma de aminoácidos ou aminas. Entretanto, dependendo da espécie, o nitrogênio é translocado das raízes à parte aérea na forma de íons e então incorporado a compostos nitrogenados (van den Driessche, 1991).

O nitrogênio é um elemento formador de compostos básicos ao metabolismo das plantas, como as proteínas, os aminoácidos e os ácidos nucléicos (Porter et al., 1991). O nitrogênio ocorre em todas as proteínas na concentração de aproximadamente $16 \%$ da massa (Bray, 1983).

\subsubsection{Aminoácidos e Proteínas}

O nitrogênio absorvido é incorporado aos compostos de carbono como amino-grupos, formando os aminoácidos e aminas. Os aminoácidos são compostos básicos para a biossíntese de proteínas, ácidos nucléicos e substâncias nitrogenadas do metabolismo secundário. Esses compostos são 
importantes materiais básicos à construção das substâncias corpóreas das plantas (Malavolta, 1997; Larcher, 2000).

Os aminoácidos estão dentro da classe dos componentes que vêm sendo chamados de "solutos osmóticos compatíveis" os quais não interferem nas funções enzimáticas (Taiz et al., 1998).

A determinação do teor de aminoácidos a partir de extratos vegetais é muito utilizada na pesquisa fisiológica, pois a reação de uma planta ou de seus órgãos a um ferimento ou a uma situação de estresse provoca a síntese de proteínas, podendo então ser caracterizada pela composição dos aminoácidos produzidos (Passos, 1996).

As proteínas são moléculas complexas constituídas por seqüências de aminoácidos. Cada proteína é formada por uma seqüência única de aminoácidos, o que determina sua função dentro da célula (Brum et al., 1994).

As proteínas são polímeros, grandes moléculas compostas por um certo número de subunidades que contém nitrogênio, designadas aminoácidos. Sendo as proteínas moléculas complexas, são formadas por várias centenas de aminoácidos. O número das diferentes seqüências de aminoácidos e, portanto, a possível variedade de moléculas de proteínas mostra-se enorme (Raven et al., 1996).

A síntese de proteínas é a função central de todas as células. Na sua ausência, o crescimento e a manutenção dos órgãos cessam e isso representa um fator limitante à taxa de crescimento das plantas. Essa síntese requer uma demanda por aminoácidos, um alto suprimento em energia e nutrientes, especialmente de nitrogênio. $O$ suprimento de nitrogênio depende da quantidade de nitrato e amônio no meio e da taxa em que estas fontes são metabolizadas em aminoácidos. Entretanto, essa ligação entre a síntese de proteínas e o fornecimento de nitrogênio não é direta, devido ao nitrato e aos aminoácidos armazenados nos vacúolos (Porter et al., 1991). 
O metabolismo das proteínas (absorção e translocação ativa de $\mathrm{N}$, processos do metabolismo basal provedores de compostos, síntese de aminoácidos, transcrição e tradução) é extremamente ativo e também dependente do tipo e idade do órgão. Órgãos em crescimento ou órgãos e tecidos de estoque são caracterizados pela síntese especialmente intensa de proteínas, entretanto, em folhas senescentes ocorre a degradação das mesmas. A síntese de proteínas é caracterizada pela alta e rápida capacidade de adaptação molecular, funcional e fisiológica, em relação ao meio (Larcher, 2000).

\subsubsection{Carboidratos}

O efeito do $\mathrm{N}$ sobre os carboidratos não é direto, se compararmos, por exemplo, seu papel como formador de compostos básicos, como os aminoácidos e proteínas, porém, conforme Mengel et al (1987), a absorção de amônio também é afetada pelo nível de carboidratos da planta. Altos níveis de carboidratos favorecem a absorção de amônio provavelmente pelo aumento da assimilação de amônia $\left(\mathrm{NH}_{3}\right)$. A absorção de nitrato pode ser diminuída pelo amônio. Por outro lado, a absorção de amônio é influenciada pelo nitrato.

A relação existente entre os teores de carbono e um nutriente específico indica que, se uma deficiência nutricional limita o crescimento mais que uma deficiência na disponibilidade de luz, os carboidratos serão acumulados no tecido vegetal. $O$ crescimento limitado indica que o excesso de carbono foi afastado da produção de metabólitos secundários constituídos de carbono. Um macronutriente mineral importante e que afeta o balanço carbono-nutriente é o nitrogênio (Hakulinen, 1998).

Os carboidratos constituem um grupo de compostos que incluem açúcares simples e moléculas mais complexas constituídas por subunidades de açúcares mais simples, cuja principal função é o fornecimento de energia química aos processos do ciclo de vida da célula. (Brum et al, 1994) 
Outras funções atribuídas aos carboidratos são: (i) fontes de reserva, como é o caso do amido; (ii) possibilitam a sustentação, como no caso da celulose, hemicelulose em vegetais; (iii) auxiliam na defesa, como no caso das glicoproteínas e imunoglobulinas, entre outras mais específicas (Vieira et al., 1991).

\subsection{Uso de Reguladores Vegetais em cultivos in vitro}

Os tecidos e órgãos vegetais cultivados 'in vitro', usualmente requerem um suprimento exógeno de auxina e citocinina para alcançarem níveis de desenvolvimento adequados (Droual et al., 1998).

A maior função atribuída por Salisbury et al. (1991) à citocinina é promover a divisão celular, enquanto que, quando somente auxina é adicionada em meios de cultivo variados, ocorre apenas a formação de massas celulares sem especialização e pouco organizadas, denominadas calos.

Salisbury et al. (1991) citam que, em relações citocinina/auxina altas, ou seja, em meios de cultura com predomínio de citocinina, há formação de células meristemáticas nos calos, as quais sofrem divisão e diferenciação em gemas, caules e folhas. Já em relações baixas, onde há predomínio de auxina, ocorre a formação de calos e raízes.

Ferri (1979) e Krikorian et al. (1988), destacam os principais efeitos biológicos das auxinas: crescimento do caule, o alongamento do caule ocorre por atividade mitótica e por aumento de volume das células meristemáticas do ápice; crescimento das folhas envolvendo divisão, expansão e diferenciação celular; crescimento das raízes, entre outros. Os autores detalham também os efeitos biológicos das citocininas, tais como: divisão celular (propriedade mais comumente atribuída às citocininas); alongamento celular; diferenciação que o autor considera ser o efeito mais marcante da citocinina, que, em ação conjunta 
com a auxina controla a morfogênese e a formação de órgãos em tecidos em cultivo; germinação; retardamento da senescência; entre outros.

Conforme Little (1984), a citocinina exógena tem sido considerada responsável pelo estímulo ao desenvolvimento das brotações laterais em muitas espécies de plantas. O autor verificou o efeito da aplicação de 600ppm de BAP na formação de brotações laterais em plantas de Abies balsamea e concluiu que a aplicação de citocinina aumentou a atividade meristemática e a formação de novas brotações laterais; a BAP também incrementou o crescimento dos brotos que já existiam nas estacas utilizadas para o experimento. A resposta das amostras à aplicação de BAP também foi relacionada aos teores de nutrientes oferecidos às plantas (principalmente $\mathrm{N}$ ) e, ao genótipo das mesmas, já que o autor não utilizou um único clone em seus experimentos. Com tal relação, o autor concluiu que a produção de brotações é maior quando o fornecimento de nutrientes às plantas está adequado. Para chegar a esta conclusão, o autor utilizou 3 níveis de $\mathrm{N}$ considerados: alto, médio e baixo e, as melhores respostas foram atingidas quando as plantas foram cultivadas em níveis médios de fornecimento de $\mathrm{N}$.

Em concordância com o trabalho de Little (1984), Spanos et al. (1997) estudaram a micropropagação de Cupressus sempervirens e Chamaecyparis lawsoniana, verificando que, brotações das duas espécies cultivadas in vitro produziram novas brotações mesmo sem a aplicação de citocininas ao meio de cultura MS, porém, em quantidade desprezível. A produção de gemas e brotações somente atingiu taxas satisfatórias quando os explantes foram expostos a concentrações de 0,01 a $1,0 \mathrm{mg} \cdot \mathrm{L}^{-1}$ de $\mathrm{BA}$ por 28 dias. O número de brotações formadas foi proporcional ao incremento na concentração da citocinina aplicada ao meio de cultura.

Estudando o processo de micropropagação e, mais precisamente, a formação de brotações adventícias em explantes de cotilédones de Pinus pinea 
L., González et al (1998) observaram que a suplementação de 4,5ìM de 6benziladenina por 30 dias no meio de cultura LePoivre à meia concentração exibiu os melhores resultados.

Chang et al (1991) indicam que a tecnologia para a propagação clonal de coníferas tem sido rapidamente desenvolvida e, sendo assim, tanto o processo de organogênese como o de embriogênese já se encontram estabelecidos para muitas espécies de Pinus. Esses autores estudaram o efeito de diferentes citocininas na formação de brotações em explantes de cotilédones de Pinus virginiana cultivados em meio de cultura GD com concentração de ANA fixa $\left(0,05 i m o l . L^{-1}\right)$. Os resultados indicam que, após 30 dias de cultivo, a benziladenina (BA), foi a citocinina mais eficiente dentre as estudadas, sendo que a formação de brotações aumentou conforme a concentração de BA aplicada ao meio de cultura $\left(4,4 ; 11,1 ; 22,2 ; 44,4\right.$ ìmol.L $\left.{ }^{-1}\right)$. A maior média de brotações por explante observada foi de 29. Segundo os autores, este é o primeiro trabalho que aponta sucesso na propagação massal do Pinus virginiana.

Denoso (1991) desenvolveu a tecnologia para a propagação massal de explantes de Larix decídua cultivados in vitro. Como explante, o autor utilizou embriões, os quais foram submetidos a 2 experimentos. Primeiramente, o autor cultivou os explantes nos meios de cultura MS (básico e à $1 / 2$ concentração), $\mathrm{SH}$, WPM, DCR (básico e à $1 \frac{2}{2}$ concentração), a fim de verificar a influência do meio de cultura no desenvolvimento dos embriões. O meio de cultura DCR foi selecionado para o segundo experimento, que objetivou avaliar o efeito de diferentes citocininas no desenvolvimento dos explantes. O melhor resultado encontrado mostra que $10 \mathrm{mg} \cdot \mathrm{L}^{-1}$ de BAP proporcionou a formação do maior número de brotações (16 por explante). O autor indica, ainda, que a presença de auxina (ANA, AIA, AIB) no meio de cultura resultou em declínio no número de brotações formadas e no aumento da incidência de calos na base dos explantes. 
Capuana et al (1997) estudaram a micropropagação do cipreste (Cupressus sempervirens L.), utilizando seedlings de 5 semanas de idade, originários de sementes como explantes. Esses explantes foram cultivados em 4 diferentes meios de cultura: MS, SH, GD e MCM, suplementados por vitaminas e 5ìmol.L ${ }^{-1}$ de BA e 0,1 ìmol. $L^{-1}$ de ANA. Após 2 a 3 semanas, já foi possível observar, macroscopicamente, a proliferação de brotações. Os meios de cultura MS e SH exibiram uma média de 4,5 brotações/explante, considerado o melhor resultado. Os autores indicam que, as coníferas geralmente produzem brotações em resposta à aplicação exógena de citocinina e a presença de BA mostrou-se essencial para que ocorra o estímulo à formação de novas brotações, tanto na espécie estudada como em outras espécies de coníferas, particularmente sob as concentrações de 5 a 10 ìmol. L $^{-1}$ em combinação com 0 ,2ìmol.L ${ }^{-1}$ de ANA.

Porém, concentrações de citocininas maiores que 10 ìmol. $\mathrm{L}^{-1}$ podem ocasionar declínio na produção de brotações axilares, como já observado em outras espécies de coníferas, como Tetraclinis articulata (Vahl) Masters (Morte et al., 1992).

Tuskan et al. (1990), cultivaram explantes de cotilédones de Pinus ponderosa var. scopulorum nos meios de cultura GD e LePoivre sob 6 combinações BA:ANA $(0,044: 5,4 ; 4,4: 0,054 ; 4,4: 5,4 ; 4,4: 54,0 ; 44,0: 0,54$ e 44,0:5,4 ìmol. $\mathrm{L}^{-1}$ ) buscando avaliar $\mathrm{o}$ efeito da auxina e citocinina no desenvolvimento dos explantes. Após 90 dias de cultivo (3 subcultivos), os autores puderam observar que as combinações entre os fitorreguladores influenciaram significativamente as massas dos calos formados em cada subcultivo. Os calos com a menor massa celular foram originados no tratamento com a menor concentração de auxina. Em contraste a esta informação, os tratamentos com as menores concentrações de BA foram associados aos calos com as maiores massas celulares. Portanto, podemos concluir que a auxina, 
mais que a citocinina, é requerida para a iniciação e proliferação dos calos em culturas de Pinus ponderosa.

Em culturas de calos estabelecidas através de vários tipos de explantes de Cryptomeria japonica, houve um limitado potencial de diferenciação e, não foram obtidas plantas completas utilizando-se os meios de cultura WS e MS. Suplementando-se o meio com ANA $\left(10^{-5} \mathrm{M}\right)$ e BAP $\left(10^{-6} \mathrm{M}\right)$ ou $\left(8.10^{-6} \mathrm{M}\right)$ obteve-se rizogênese, mas não foram observadas brotações (sikawa, 1984 e Isikawa, 1987).

Harry et al. (1994) estabeleceram um protocolo para a organogênese de Pinus banksiana, a partir de embriões cultivados em meio MCM e verificaram que os melhores resultados (6 plântulas/embrião) foram obtidos quando o meio de cultura foi suplementado por $10 \mu \mathrm{mol}^{.} \mathrm{L}^{-1}$ de BAP.

A multiplicação 'in vitro' de brotações de Pseudotsuga menziesii e de Pinus lambertiana foi estudada por Gupta et al. (1985) em diferentes composições de meio de cultura: MS, WPM e DCR modificado. Os autores verificaram que a produção de brotações foi incrementada quando se utilizou 0,5mg. $\mathrm{L}^{-1}$ de BAP para o Pinus e $0,2 \mathrm{mg} \cdot \mathrm{L}^{-1}$ para a $P$. menziesii no meio DCR., considerando que a composição do meio DCR é a que leva menos $\mathrm{N}$ entre nitrato e amônio. 


\section{METODOLOGIA}

\subsection{Metodologia Geral}

Os experimentos realizados envolveram estudos com diferentes concentrações de nitrato e amônio fornecidas ao meio de cultura MS como fontes de nitrogênio. Com isso, variamos também a concentração de $\mathrm{N}$ total no meio $\mathrm{e}$ as relações nitrato:amônio presentes.

As composições de meio de cultura que apresentaram os melhores resultados em termos de taxa de crescimento relativo (TCR), teores de proteínas solúveis totais, carboidratos não estruturais totais e aminoácidos solúveis totais no experimento descrito acima foram selecionadas e utilizadas para a realização do experimento com reguladores vegetais (ANA e BAP).

Antes de chegar ao número de explantes necessários ao

desenvolvimento dos experimentos, fez-se necessário introduzir e multiplicar o material sob condições de cultivo 'in vitro'.

\subsubsection{Introdução e multiplicação do material vegetal 'in vitro'}

Ápices caulinares de aproximadamente $1 \mathrm{~cm}$ de comprimento, originários de matrizes de Cryptomeria japonica D. Don "elegans" cultivadas sob condições de campo foram desinfetados através de lavagem com água corrente durante 5 minutos e imersos em solução 20\% (V/V) de hipoclorito de sódio comercial $(\mathrm{NaOCl})$ durante 20 minutos, sob leve agitação. Em seguida, dentro da 
câmara de fluxo laminar, os explantes passaram por três lavagens com água esterilizada e, em seguida, foram inoculados em tubos de ensaio contendo $15 \mathrm{~mL}$ de meio de cultura MS básico, isento de fitorreguladores. Os explantes iniciais já inoculados foram mantidos em câmara de cultivo, com a finalidade de obtenção do número ideal de explantes secundários (brotações) para a instalação do experimento. O material vegetal repicado a cada 30 dias durante a fase de multiplicação dos explantes.

As brotações advindas dos calos formados na base dos ápices caulinares originaram os explantes secundários, utilizados para a condução dos experimentos realizados.

\subsection{Concentrações de Nitrogênio utilizadas e instalação do experimento}

Foram utilizadas as concentrações de nitrato $\left(\mathrm{NO}_{3}{ }^{-}\right)$e amônio $\left(\mathrm{NH}_{4}{ }^{+}\right)$ descritas na Tabela 1. Ao todo, foram empregadas 10 variações nas relações entre as fontes de nitrogênio e, conseqüentemente, no teor de $\mathrm{N}$ total, constituindo-se os meios de cultura denominados como tratamento 1 a tratamento 10.

Tabela 1. Relações nitrato:amônio utilizadas nos diferentes tratamentos.

\begin{tabular}{|c|c|c|c|c|c|c|c|c|c|}
\hline & $\mathrm{NO}_{3}^{-}$ & $\mathrm{NH}_{4}^{+}$ & $N$ total & & & $\mathrm{NO}_{3}^{-}$ & $\mathrm{NH}_{4}^{+}$ & $N$ total & \\
\hline trat & & $\mathrm{mmol}^{\prime-\mathrm{L}^{-1}}$ & & Rel & trat & & $\mathrm{mmol} \cdot \mathrm{L}^{-1}$ & & Rel \\
\hline 1 & 40,0 & 20,0 & 60,0 & $2: 1$ & 6 & 41,0 & 15,0 & 56,0 & $2,7: 1$ \\
\hline 2 & 35,0 & 15,0 & 50,0 & 2,3:1 & 7 & 36,0 & 10,0 & 46,0 & $3,6: 1$ \\
\hline 3 & 30,0 & 10,0 & 40,0 & $3: 1$ & 8 & 31,0 & 5,0 & 36,0 & $6,2: 1$ \\
\hline 4 & 25,0 & 5,0 & 30,0 & $5: 1$ & 9 & 28,5 & 2,5 & 31,0 & $11,4: 1$ \\
\hline 5 & 22,5 & 2,5 & 25,0 & 9:1 & 10 & 26,0 & 0,0 & 26,0 & $26: 0$ \\
\hline
\end{tabular}


O tratamento 1 (T1) corresponde às concentrações aproximadas de amônio e nitrato presentes no meio de cultura MS, considerado o controle.

Todos os tratamentos foram também suplementados por $0,5 \mathrm{mg} \cdot \mathrm{L}^{-1}$ de BAP e 0,1 mg. L $^{-1}$ de ANA, com pH ajustado em 5,8.

As concentrações de nitrato e amônio fornecidas aos explantes (Tabela 1) foram calculadas utilizando-se a combinação entre $\mathrm{NH}_{4} \mathrm{NO}_{3}$ e $\mathrm{KNO}_{3}$ para todos os tratamentos. Entretanto, para os tratamentos 6 a 10, além do nitrato de amônio e do nitrato de potássio, os meios de cultura receberam também, 3mM de $\mathrm{Ca}\left(\mathrm{NO}_{3}\right)_{2} \cdot 4 \mathrm{H}_{2} \mathrm{O}$ em substituição à igual concentração de $\mathrm{Ca}(\mathrm{Cl})_{2} \cdot 2 \mathrm{H}_{2} \mathrm{O}$ (presente no meio de cultura MS básico), para a complementação das concentrações de nitrato e amônio desejadas nos diferentes tratamentos propostos. Como a concentração oferecida dos dois sais foi semelhante, não houve problemas quanto ao fornecimento de cálcio aos explantes.

Dentre as fontes de amônio e nitrato normalmente utilizadas em meios de cultura, foram utilizados os sais $\mathrm{NH}_{4} \mathrm{NO}_{3}$ e $\mathrm{KNO}_{3}$ visando evitar possíveis efeitos de toxidez por $\mathrm{Cl}$, quando a fonte de amônio é o $\mathrm{NH}_{4} \mathrm{Cl}$ ou ainda para evitar possíveis precipitações de outros íons no meio de cultura pela presença do sulfato $\left(\mathrm{SO}_{4}{ }^{2-}\right)$, quando a fonte é o $\left(\mathrm{NH}_{4}\right)_{2} \mathrm{SO}_{4}$.

O material vegetal foi mantido em câmara de cultivo, com fotoperíodo de 16 horas, temperatura de $25 \pm 2^{\circ} \mathrm{C}$ e PAR (Radiância Fotossinteticamente Ativa) de $50 \mu \mathrm{mol} \cdot \mathrm{m}^{-2} \cdot \mathrm{s}^{-1}$.

Os ensaios foram realizados em blocos inteiramente casualizados, com 8 repetições por tratamento e 5 explantes por frasco contendo $40 \mathrm{~mL}$ de meio de cultura MS modificado conforme os tratamentos descritos. As retiradas de amostras para as análises realizadas foram feitas aleatoriamente na instalação do experimento, a cada subcultivo e ao final de 90 dias, para os ensaios bioquímicos. 


\subsection{Avaliações dos dados}

\subsubsection{Determinação da massa vegetal seca}

Primeiramente, foram avaliadas as massas dos materiais vegetais frescos na data de montagem do experimento (dados iniciais), aos 30, aos $60 \mathrm{e}$ aos 90 dias de cultivo. Posteriormente, o material foi submetido ao processo de secagem em estufa a uma temperatura de $60 \pm 5^{\circ} \mathrm{C}$ por um período superior a 48 horas, até massa seca constante.

\subsubsection{Análise da taxa de crescimento relativo (TCR)}

Os dados obtidos com a pesagem do material vegetal seco foram utilizados para a elaboração da Taxa de Crescimento Relativo (TCR), segundo a equação descrita por Hunt (1982):

$$
T C R=\frac{\ln P M S(X n)-\ln P M S(X 0)}{T(X n)-T(X o)}
$$

onde: Ln: logaritmo Neperiano; PMS(Xn): Massa do material vegetal seca, sendo a média tomada ao final de cada período amostral; PMS(Xo): Massa do material vegetal seco, sendo a média tomada ao início de cada período amostral; 
$\mathbf{T}(\mathbf{X N})$ : Tempo final do período amostral; $\mathbf{T}(\mathbf{X o})$ : Tempo inicial do período amostral.

\subsubsection{Quantificação de Proteínas Solúveis totais (Bradford, 1976)}

\subsubsection{Extração de Proteínas Solúveis Totais}

Amostras de explantes de Cryptomeria japonica D. Don. "elegans" totalizando aproximadamente $500 \mathrm{mg}$ (massa vegetal fresca) foram maceradas em gral de porcelana contendo 4,0mL da solução de extração (Apêndice 1). Após este procedimento, o material vegetal permaneceu por 1 hora em reação à temperatura ambiente e, em seguida, as amostras foram aquecidas até o ponto de fervura em banho-Maria $\left(100^{\circ} \mathrm{C}\right)$, permanecendo em reação por mais 3 minutos.

Após o resfriamento das amostras em temperatura ambiente, estas foram centrifugadas a 12.000 rpm durante 300 segundos, obtendo-se desta forma o extrato bruto. O sobrenadante foi utilizado para a quantificação do teor de proteínas solúveis totais e o "pellet" residual formado foi descartado.

\subsubsection{Quantificação de proteínas totais}

Primeiramente, foi obtida uma curva analítica de calibração a partir dos seguintes padrões: $0 ; 10 ; 20 ; 40 ; 60 ; 80 ; 100 ; 120 ; 140 ; 160 ; 180 ; 200 \mathrm{mg}$ de albumina. $\mathrm{L}^{-1}$. A um volume de $500 \mu \mathrm{L}$ de solução $\mathrm{NaCl} 0,5 \mathrm{M}$ adicionou-se $4,5 \mathrm{~mL}$ de solução de Comassie (Apêndice 1).

A curva analítica de calibração foi estabelecida a um comprimento de onda de 595nm em espectrofotômetro e com ela obteve-se a equação da reta 
através da qual foi possível a determinação do teor de proteínas totais em cada tratamento (em mg de proteínas. $\mathrm{g}^{-1}$ de material vegetal fresco).

Para a quantificação dos teores de proteínas totais nas amostras, adicionou-se $50 \mu \mathrm{L}$ de amostra a $4,5 \mathrm{~mL}$ de solução de Comassie e procedeu-se à leitura a $595 \mathrm{~nm}$.

\subsubsection{Eletroforese de Proteínas Solúveis Totais em Gel de Poliacrilamida (Alfenas et al., 1991)}

Após a confecção e polimerização do gel de poliacrialmida (Apêndice

2), este foi levado à cuba de corrida de eletroforese, a qual foi preenchida com o tampão de corrida (Apêndice 2).

As amostras foram adicionadas nos poços formados no gel espaçador e a corrida foi realizada em geladeira, utilizando fonte para eletroforese (Pharmacia EPS 300), com corrente elétrica de $75 \mathrm{~mA}$, por um período de aproximadamente 3 horas.

Finalizada a corrida do gel, este foi retirado da cuba e imediatamente imerso em Solução Fixadora (Apêndice 2), por um período de, no mínimo, 12 horas, para o início do processo de revelação do gel. A seguir, foi aplicada uma série de soluções sobre o gel, que constituem o Método de coloração com Prata (Apêndice 2).

Após este procedimento, o gel foi fotografado, filmado e analisado através do software Kodak Digital Science 1D (Kodak).

\subsubsection{Determinação de Carboidratos não-estruturais totais pelo Método de Antrona (Yenm \& Willis, 1954)}

\subsubsection{Extração dos Carboidratos não-estruturais totais}


Amostras de material vegetal fresco de aproximadamente $500 \mathrm{mg}$ de explantes de Cryptomeria japonica D. Don "elegans" foram maceradas em gral de porcelana contendo $10 \mathrm{~mL}$ de etanol $80 \%(\mathrm{~V} / \mathrm{V})$ e filtradas em papel de filtro Whatman n̊1. O volume filtrado foi mantido em estufa à vácuo a $45^{\circ} \mathrm{C}$, até a evaporação total do álcool (aproximadamente 24 horas).

Após a evaporação, o material que permaneceu aderido ao fundo do frasco foi novamente suspenso em $30 \mathrm{~mL}$ de água destilada deionizada.

\subsubsection{Determinação com reagente de antrona}

Primeiramente, foi obtida uma curva analítica de calibração, com os seguintes padrões de glicose: 0; 25; 50; 75; 100; 125; 150; 175; 200 mg de glicose $\mathrm{L}^{-1}$. De cada padrão, pipetou-se $1 \mathrm{~mL}$, o qual foi adicionado a $7 \mathrm{~mL}$ do reagente de antrona (Apêndice 3). A solução foi agitada e aquecida em banhoMaria $\left(100^{\circ} \mathrm{C}\right)$ por 10 minutos. Após o resfriamento em gelo, procedeu-se à leitura a $625 \mathrm{~nm}$ em espectrofotômetro obtendo-se a curva analítica de calibração e a equação da reta que melhor se adaptou aos pontos obtidos. Procedeu-se então à leitura das amostras e, com a equação obtida mediante a curva analítica de calibração, foi possível a estimativa da concentração de carboidratos nãoestruturais totais (em mg de glicose. $\mathrm{g}^{-1}$ de material vegetal fresco) para cada tratamento proposto.

\subsubsection{Determinação de aminoácidos solúveis totais (Passos, 1996)}

\subsubsection{Extração de Aminoácidos Solúveis Totais}

Amostras de aproximadamente $300 \mathrm{mg}$ (massa do material vegetal fresco) de explantes de Cryptomeria japonica D. Don. "elegans" foram 
maceradas em gral de porcelana contendo $10 \mathrm{~mL}$ de solução MCA (12 partes de metanol:5 partes de clorofórmio:3 partes de água destilada deionizada). $O$ extrato obtido foi submetido à centrifugação (Centrífuga Excelsa Baby - Fanem) por 15 minutos a $3000 \mathrm{rpm}$.

De cada amostra, foi retirada uma alíquota de $3 \mathrm{~mL}$ que posteriormente foi acrescida de $3 \mathrm{~mL}$ de água destilada deionizada e $3 \mathrm{~mL}$ de clorofórmio. Foi coletado $1 \mathrm{~mL}$ da camada superficial da mistura bifásica formada para a continuidade do processo. O restante da solução foi descartado.

\subsubsection{Determinação quantitativa}

Preparo da Curva Analítica de Calibração:

A curva analítica de calibração foi confeccionada com os seguintes padrões de leucina: $0 ; 25 ; 50 ; 75 ; 100 ; 125 ; 150 ; 175 ; 200 \mathrm{mg}$ de leucina. $\mathrm{L}^{-1}$. De cada padrão, pipetou-se $1 \mathrm{~mL}$ ao qual foram adicionados $2 \mathrm{~mL}$ do reagente de ninidrina. A solução foi agitada e aquecida em banho-Maria $\left(100^{\circ} \mathrm{C}\right)$ durante 15 minutos e, posteriormente, acrescida de $6 \mathrm{~mL}$ de etanol $50 \%$. Após resfriamento em gelo, procedeu-se a leitura em espectrofotômetro a um comprimento de onda de $570 \mathrm{~nm}$.

Preparo e Leitura das amostras:

A uma alíquota de $1 \mathrm{~mL}$ de amostra foram adicionados $2 \mathrm{~mL}$ do reagente de ninidrina (Apêndice 4). Os tubos de ensaio, contendo a solução formada, foram vedados e agitados manualmente, para a obtenção de uma mistura homogênea. A seguir, foram aquecidos em banho-maria $\left(100^{\circ} \mathrm{C}\right)$ durante 15 minutos. Após o aquecimento, foram adicionados, em cada tudo de ensaio, $5 \mathrm{~mL}$ de etanol $50 \%$. Os tubos foram resfriados em temperatura ambiente e agitados manualmente. 
A leitura das amostras foi realizada em seguida e, com a equação da reta obtida mediante a curva analítica de calibração, foi possível estimar a

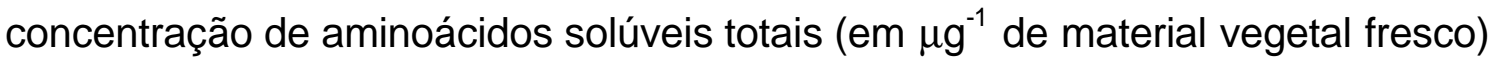
para cada tratamento proposto.

\subsection{Experimento com Reguladores Vegetais}

Os tratamentos resultantes do experimento com diferentes concentrações de nitrato e amônio que apresentaram resultados mais satisfatórios quanto às variáveis analisadas foram selecionados e utilizados para a condução do experimento com reguladores vegetais: T1 (controle); T4; T5; T9 e T10.

Estes tratamentos continuaram a receber a suplementação já descrita em sacarose e agar (30g. $\mathrm{L}^{-1}$ e $5,5 \mathrm{~g} \cdot \mathrm{L}^{-1}$, respectivamente), porém também foram suplementados pelas relações ANA:BAP descritas na Tabela 2.

Tabela 2. Relações ANA:BAP utilizadas nos diferentes tratamentos.

\begin{tabular}{ccccc}
\hline & \multicolumn{4}{c}{ ANA $\left(\mathrm{mg} \cdot \mathrm{L}^{-1}\right)$} \\
\hline $\mathrm{BAP}\left(\mathrm{mg} \cdot \mathrm{L}^{-1}\right)$ & 0,00 & 0,25 & 0,50 & 1,00 \\
\hline 0,50 & $\mathrm{t} 1$ & $\mathrm{t} 2$ & $\mathrm{t} 3$ & $\mathrm{t} 4$ \\
1,00 & $\mathrm{t} 5$ & $\mathrm{t} 6$ & $\mathrm{t} 7$ & $\mathrm{t} 8$ \\
2,00 & $\mathrm{t} 9$ & $\mathrm{t} 10$ & $\mathrm{t} 11$ & $\mathrm{t} 12$ \\
\hline
\end{tabular}

tx: tratamentos empregados no experimento com reguladores vegetais. A letra $t$ foi utilizada para a diferenciação dos tratamentos com diferentes concentrações de nitrato e amônio $(\mathrm{Tx})$.

Assim, o estudo com reguladores vegetais foi constituído por 12 tratamentos, com 8 repetições por tratamento e com 4 explantes por frasco, para 
cada meio de cultura utilizado. O experimento foi conduzido em blocos inteiramente casualizados.

As avaliações do material vegetal foram realizadas a cada 30 dias,

durante 3 subcultivos. Os seguintes dados foram obtidos: massa das matérias fresca e seca das amostras; número e altura média das brotações formadas; sendo que a formação de calos e raízes também foi observada.

\subsection{Análise do Gel de Eletroforese}

A análise do gel de poliacrilamida foi realizada através do software Kodak Digital Science 1D (Kodak), para a constatação da formação de bandas protéicas segundo o padrão de proteínas utilizado.

\subsection{Análise Estatística}

Todos os tratamentos, em todos os experimentos e análises realizadas, foram submetidos inicialmente ao teste de análise de variância (Anova), visando a verificação de diferença significativa para $p<0,05$.

Uma vez constatada essa diferença, foi aplicado o Teste de Tukey, para a comparação de médias. 


\section{RESULTADOS E DISCUSSÃO}

\subsection{Análise da Taxa de Crescimento Relativo (TCR) e Incremento em Massa vegetal Seca}

A Figura 1 mostra os gráficos das taxas de crescimento relativas obtidas aos 30, 60 e 90 dias de cultivo 'in vitro', segundo o tratamento aplicado.

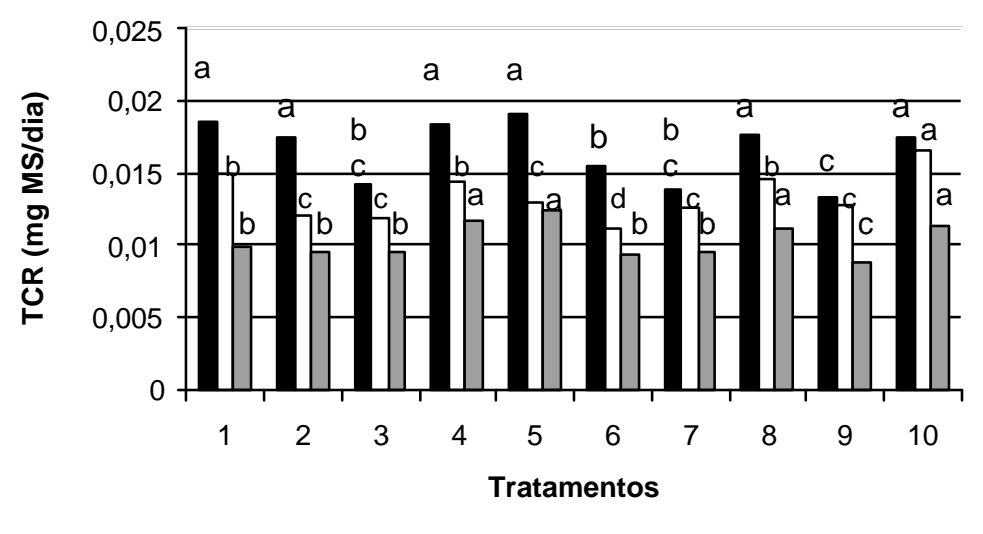

• 30 dias $\square 60$ dias $\square 90$ dias

Figura 1 - Taxa de Crescimento Relativo (TCR) dos explantes de Cryptomeria japonica D. Don "elegans" cultivados 'in vitro' sob diferentes concentrações de $\mathrm{NO}_{3}{ }^{-}$e $\mathrm{NH}_{4}{ }^{+}$(Tabela 1). Análise de comparação de médias realizada segundo a legenda. As barras que contém as mesmas letras não apresentaram diferenças significativas segundo o Teste de Tukey $(p<0,05)$. 
As maiores taxas de crescimento relativo (TCR) ocorreram no primeiro subcultivo (30 dias) para todos os tratamentos analisados, sendo que os tratamentos que apresentaram os maiores valores de TCR (em \% ao dia) foram: T1-controle (1,90\%), T2 (1,75\%), T4 (1,85\%), T5 (1,91\%), T8 $(1,80 \%)$ e T10 (1,75\%). Esses tratamentos foram os que apresentaram valores superiores de TCR também para os 60 e 90 dias, porém, com médias inferiores às médias obtidas 30 dias. Aos 90 dias, as médias encontradas foram: T1 (1,06\%), T4 $(1,18 \%)$, T5 $(1,24 \%)$, T8 $(1,12 \%)$ e T10 $(1,13 \%)$, sendo que os demais tratamentos obtiveram médias de TCR menores que $1 \%$ ao dia.

Marschner (1986), indica que as maiores taxas de crescimento relativo nos períodos iniciais de crescimento devem-se à maior velocidade de absorção dos nutrientes pela planta nesse período, quando o meio de cultura está mais favorável ao transporte e troca de íons. O maior número de sítios de ligação livres na parede e estrutura celular também é uma causa apontada para explicar as maiores taxas de crescimento iniciais.

Os resultados encontrados concordam com Slocum et al. (1983) que afirmam que a planta tem um maior crescimento em períodos iniciais de cultivo, até atingir o ponto de máximo incremento em massa. Passado esse ponto, os níveis de incremento tornam-se decrescentes, diminuindo, assim, a taxa de crescimento relativo.

Considerando as afirmações de Lee et al. (1984) e Hepler et al. (1985), que partem do princípio que a taxa de crescimento relativo (TCR) é influenciada diretamente pelas condições em que a planta cresce, pelas condições ambientais, pelas características genéticas e pelas condições internas das células, podemos indicar que os explantes cultivados nos meios de cultura com teores reduzidos de nitrato e amônio denominados T4, T5, T8 e T10 não tiveram seu desenvolvimento prejudicado pelas menores concentrações das fontes de $\mathrm{N}$ fornecidas, exibindo valores de TCR próximos ao controle (T1) aos 30 dias e, superiores ao controle aos 90 dias. Esse fato pode ser ilustrado pelas Figuras 2, 3 e 4. 
As afirmações acima também estão de acordo com as conclusões de Ingestad et al. (1995), as quais indicam que as melhores taxas de crescimento relativo são encontradas em plantas que possuem as melhores condições genotípicas e fenotípicas para o seu crescimento.

Em cultivos 'in vitro', as condições do ambiente são determinadas e controladas, portanto, o meio de cultura é um dos fatores que mais influenciam o desenvolvimento do material cultivado, determinando também o seu estado nutricional. A presença, a concentração e as inter-relações entre os nutrientes determinam a expressão do máximo crescimento vegetativo. Esses fatores variam conforme a espécie cultivada e o meio em que se encontram.

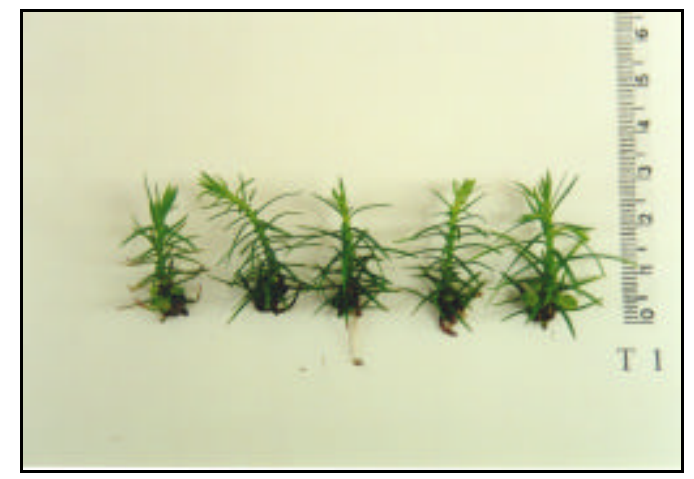

Figura 2 - Explantes de Cryptomeria japonica D. Don "elegans" mantidos em meio de cultura MS (T1 = controle) após 90 dias de cultivo 'in vitro'. Nota-se a formação de pequenos calos, porém a formação de gemas foi baixa e menor do que a observada em outros tratamentos analisados. Nota-se também a formação de raiz, porém este evento foi de ocorrência esporádica.

Pelo comportamento dos explantes mantidos sob T1, observou-se que o teor de nitrogênio mais alto, contido na composição do meio de cultura MS (T1), não favoreceu o incremento de massa seca, nem a formação de brotações, havendo somente a ocorrência de calos. A seguir, podemos 
visualizar o comportamento dos explantes mantidos sob os tratamentos T4; T5; T8 e T10 nas Figuras 3 e 4.
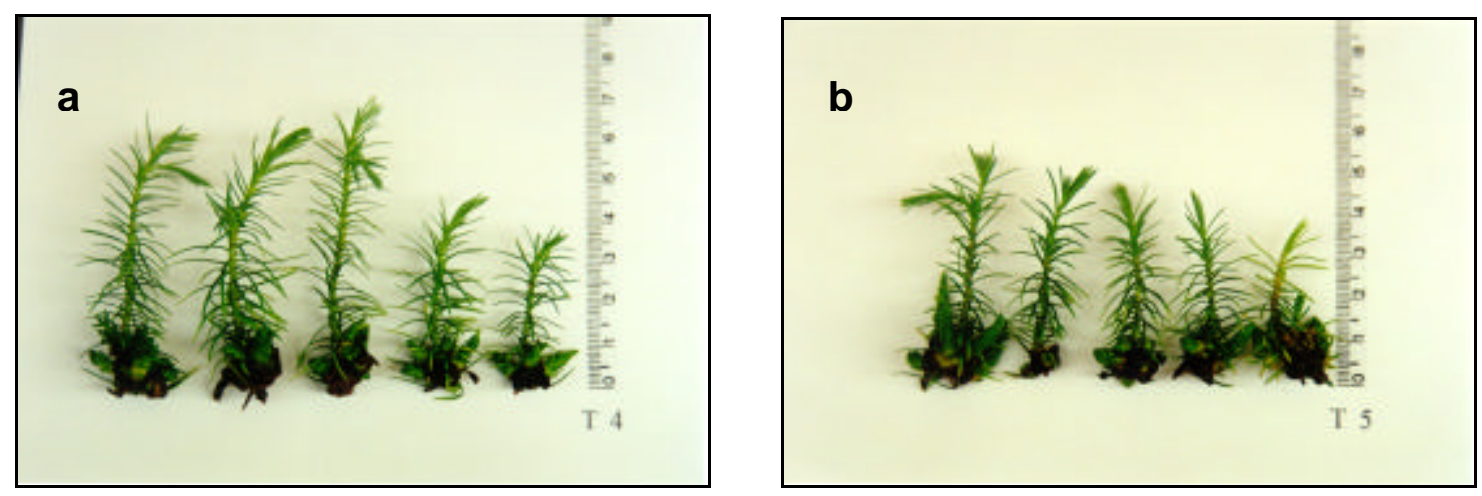

Figura 3 - Explantes de Cryptomeria japonica D. Don. "elegans" aos 90 dias de cultivo 'in vitro', sob os tratamentos: (a) T4: $25 \mathrm{mmol}^{-\mathrm{L}^{-1}}$ de $\mathrm{NO}_{3}{ }^{-}+$ $5 \mathrm{mmol} . \mathrm{L}^{-1}$ de $\mathrm{NH}_{4}{ }^{+}\left(30 \mathrm{mmol}^{-L^{-1}}\right.$ de N) e (b) T5: $22,5 \mathrm{mmol} . \mathrm{L}^{-1}$ de $\mathrm{NO}_{3}{ }^{-}$e $2,5 \mathrm{mmol}^{-\mathrm{L}^{-1}}$ de $\mathrm{NH}_{4}{ }^{+}\left(25 \mathrm{mmol} . \mathrm{L}^{-1}\right.$ de N$)$. Tanto em T4 como em T5, nota-se a formação de calos e brotações em maior quantidade que em T1.
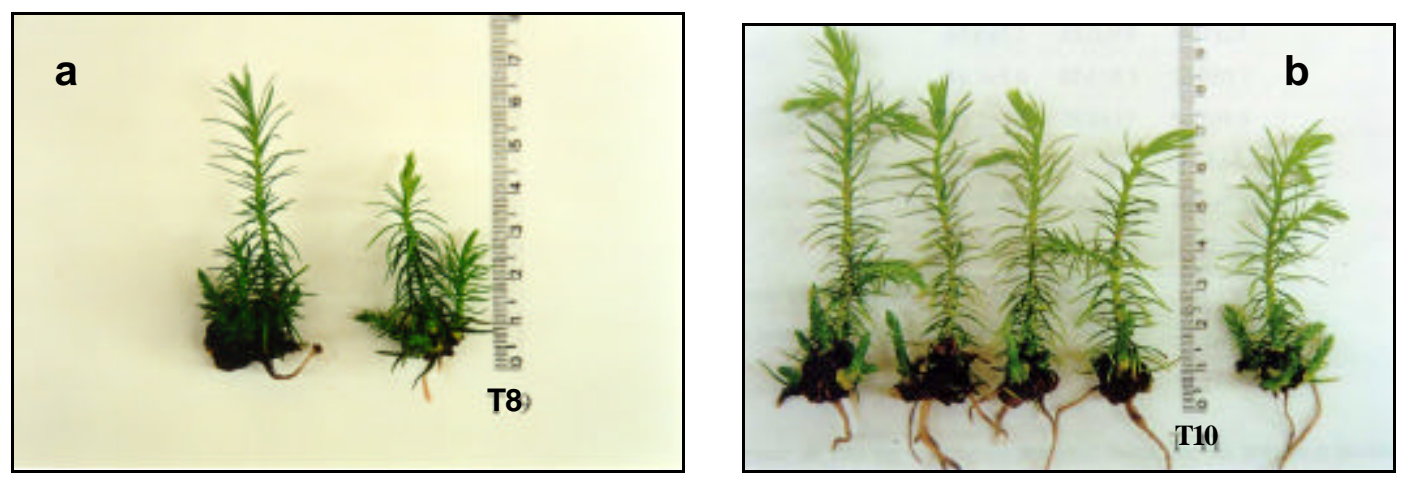

Figura 4 - Explantes de Cryptomeria japonica D. Don. "elegans" aos 90 dias de cultivo 'in vitro', sob os tratamentos: (a) T8 $\left(31 \mathrm{mmol}^{-\mathrm{L}^{-1}}\right.$ de $\mathrm{NO}_{3}{ }^{-}+$ 5 mmol.L-1 de $\mathrm{NH}_{4}^{+}$), onde observou-se a formação de calos, brotações e pequenas raízes e (b) T10 (26mmol.L-1 de nitrato), onde nota-se a intensa formação de calos, brotações e raízes. 
As Figuras 3 e 4 ilustram o comportamento superior observado nos explantes mantidos sob os tratamentos T4, T5, T8 e T10 em relação ao controle (T1), em produção de calos e brotações. Na Figura 5 observam-se os níveis de incremento em massa vegetal seca por subcultivo analisado para os diferentes tratamentos.

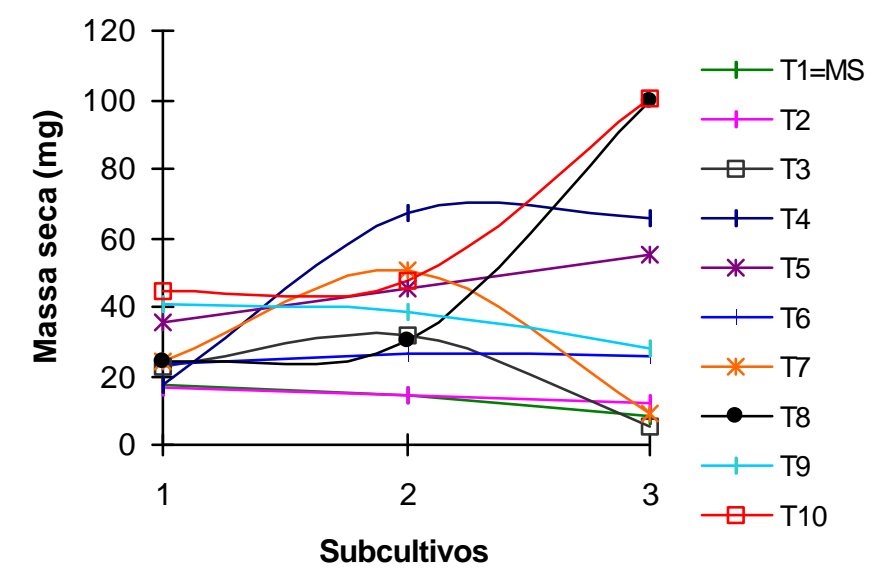

Figura 5 - Incremento médio em massa vegetal seca $(\mathrm{mg})$ por subcultivo analisado (1, 2 e 3 correspondendo a 30, 60 e 90 dias respectivamente) em explantes de Cryptomeria japonica D. Don. "elegans" cultivados 'in vitro' sob diferentes concentrações de nitrato e amônio. O T1 refere-se ao meio de cultura MS, considerado o controle.

Os tratamentos T5, T8 e T10 apresentaram aumento na produção de massa vegetal seca durante os 3 subcultivos analisados e, conforme a Figura 5 ilustra, a produção indica uma tendência crescente mesmo ao final de 90 dias. Já o tratamento T4 apresentou incremento crescente em massa vegetal seca aos 30 e 60 dias, tendendo a um equilíbrio dos 60 aos 90 dias. O incremento em massa seca esteve relacionado à maior formação de calos, brotações e 
também ao próprio crescimento dos explantes iniciais, mantidos sob os tratamentos citados.

Os demais tratamentos apresentaram queda na produção de massa seca a partir dos 30 dias de cultivo, com exceção do T2 e T6, os quais apresentaram uma certa constância na produção de massa vegetal seca, porém em baixo nível. Esses tratamentos são os que apresentam as maiores quantidades de amônio (10 a $\left.20 \mathrm{mmol} . \mathrm{L}^{-1}\right)$ e também alta concentração de nitrato (30 a $41 \mathrm{mmol}^{-\mathrm{L}^{-1}}$ ).

Conforme Ingestad et al. (1995), o equilíbrio encontrado em alguns tratamentos indica que possivelmente está havendo um equilíbrio entre a taxa de absorção de nutrientes e a conversão em massa vegetal seca. E, a redução no incremento de material vegetal seco pode estar associada a um esgotamento do meio de cultura e das condições favoráveis de crescimento da espécie, já que as condições ambientais e a necessidade específica de nutrientes para cada espécie podem estar influenciando o seu crescimento.

Por outro lado, os tratamentos que apresentaram maiores valores de TCR (Figura 1) também exibiram comportamento diferenciado em relação ao incremento em massa seca, conforme já especificado acima. Isso pode estar relacionado às afirmações delngestad et al. (1995) e Van den Driesshe (1991), autores que indicam que o meio de cultivo deve estar adequado às necessidades nutricionais da cultura. Sendo a espécie cultivada uma conífera, que, segundo consta em diversos trabalhos selecionados na revisão bibliográfica, pode apresentar níveis superiores de crescimento quando cultivada sob regimes de menor fornecimento de alguns nutrientes, em especial $\mathrm{N} \mathrm{e}$, pode responder diferentemente às fontes de $\mathrm{N}$ oferecidas no meio de cultura, o incremento crescente em massa seca pode indicar a manutenção das condições adequadas de crescimento e desenvolvimento 'in vitro' da espécie.

Pode-se indicar, portanto, que as concentrações de nitrato e amônio presentes nos tratamentos T4, T5, T8 e T10, não foram fatores limitantes ao 
crescimento e desenvolvimento dos explantes cultivados 'in vitro', quando comparados ao controle.

Os resultados encontrados pela análise da TCR e incremento em massa vegetal seca podem ser relacionados às conclusões de Adams et al. (1982), que mensuraram maiores níveis de crescimento em Eucalyptus regnans e Pinus radiata suplementados por nitrato somente (42ppm), ou por tratamentos onde a concentração de nitrato superou a de amônio (28ppm e 14ppm respectivamente). Entretanto, apesar do maior crescimento exibido, a taxa de acúmulo de nitrato nos tecidos foi menor que a de amônio. Os autores relacionam o maior crescimento alcançado à atividade da nitrato-redutase, que preveniu o efeito tóxico do acúmulo de nitrato.

Amâncio et al. (1993) verificaram melhores índices de crescimento em calos de milho cultivados com o fornecimento de nitrato juntamente com amônio. O suprimento de apenas amônio $\left(7 \mathrm{mmol}^{-1} \mathrm{~L}^{-1}\right)$ ocasionou um decréscimo de $55 \%$ na taxa de crescimento dos calos, o qual foi atribuído a inibição na atividade de algumas enzimas chaves, como a PEP-carboxilase, assim como mudanças no $\mathrm{pH}$ citoplasmático das células. Em meios de cultura suplementados apenas por nitrato, verificou-se um crescimento de $80 \% \mathrm{em}$ comparação ao controle (100\%). Esses resultados foram considerados semelhantes aos encontrados em estudos com soja (Glycine max) e rosa (Rosa sp.).

Outro fator que poderia contribuir aos resultados encontrados, está no estudo realizado por Vollbrecht et al. (1989) que indicam que o amônio pode ser tóxico ao crescimento e metabolismo de várias espécies e que algumas espécies, como a Sinapsis alba (mostarda), conseguem contornar os efeitos tóxicos do amônio pelo desenvolvimento de um mecanismo flexível de controle do seu metabolismo. Outras espécies, sobretudo as coníferas, como o Pinus sylvestris, possuem baixa adaptabilidade metabólica aos níveis excessivos de amônio presentes no meio de cultivo, por apresentarem, de um modo geral, um metabolismo mais rígido. 


\subsection{Conteúdo de Proteínas Solúveis Totais}

A Figura 6 mostra a curva analítica de calibração de albumina, obtida para a quantificação do teor de proteínas solúveis totais no material vegetal submetido à análise, a qual apresentou-se adequada $\left(R^{2}=0,95\right)$ para a leitura das amostras dos diferentes tratamentos aplicados.

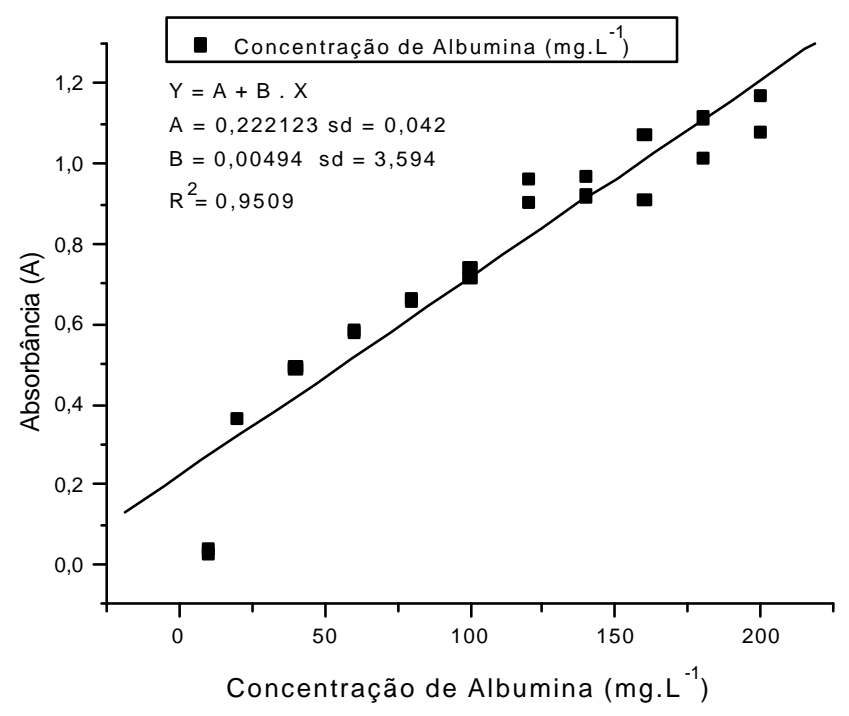

Figura 6 - Curva Analítica de calibração para albumina.

Na Figura 7, é possível verificar que não houve grande oscilação no teor de proteínas solúveis totais entre os tratamentos aplicados. Porém, a diferença entre os níveis de proteínas encontrados nas amostras apresentou diferença significativa conforme a análise estatística empregada.

Numa análise visual, o tratamento que mais acumulou proteínas foi o T3, que contém aproximadamente 35\% menos nitrogênio que o controle ( $\mathrm{T} 1=$ MS), porém, estatisticamente, não houve diferença significativa segundo o teste de Tukey $(p<0,05)$, quando comparamos o T3 ao controle (T1) e aos tratamentos 
T2 e T11. Pode-se indicar, assim, que níveis menores de $\mathrm{N}$ em relação ao controle não causaram grandes oscilações na síntese de proteínas solúveis totais necessárias ao metabolismo dos explantes cultivados 'in vitro'.

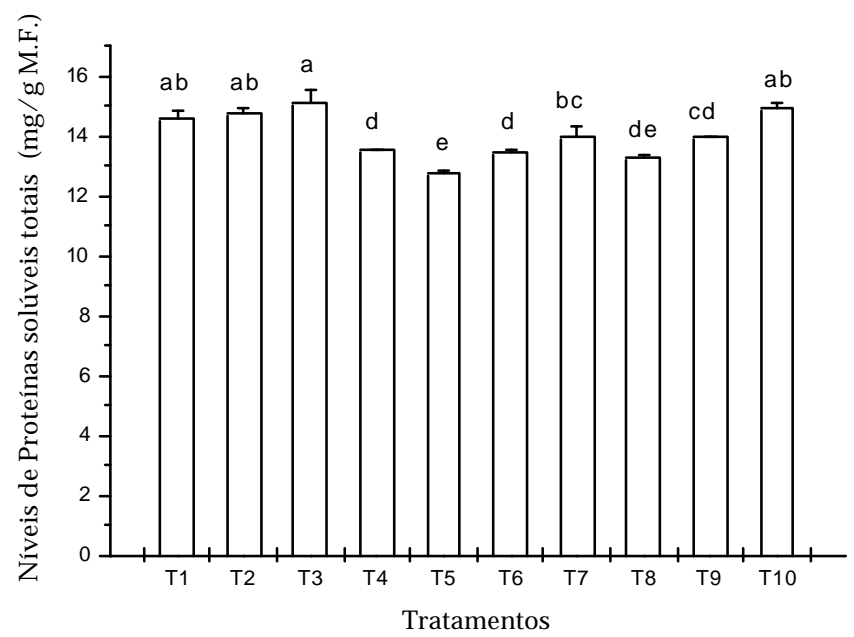

Figura 7 - Conteúdos de proteínas solúveis totais encontrados ao final de 90 dias de cultivo 'in vitro' de explantes de Cryptomeria japonica D. Don. "elegans" mantidos sob as diferentes concentrações de $\mathrm{NO}_{3}{ }^{-}$e $\mathrm{NH}_{4}{ }^{+}$ propostas (Tabela 1). As barras que apresentam as mesmas letras referem-se aos tratamentos que não diferiram significativamente entre si, conforme o Teste de Tukey, para $p<0,05$.

Os níveis de proteínas solúveis totais observados na Figura 7 estão de acordo com os resultados obtidos por Khamis et al. (1990). Os autores apontam que, o teor de proteínas solúveis totais foi diretamente proporcional ao suprimento de nitrato fornecido às plantas e, portanto, sob menores concentrações de $\mathrm{NO}_{3}{ }_{3}$, a síntese de proteínas foi menor. Em plantas de milho, os autores verificaram diminuição drástica na taxa de crescimento sob níveis baixos de nitrato e também o aparecimento de sintomas de deficiência de N, o que não foi observado nos 
explantes de $C$. japonica cultivados 'in vitro'. A relação entre nitrato e proteínas descrita pode ser comparada aos resultados encontrados em T4, T5 e T8, porém, a síntese de proteínas solúveis totais não acompanhou esta tendência para T10.

Porém, os mesmos autores indicam que, a partir de uma determinada concentração de nitrato fornecida ao material vegetal, as diferenças encontradas nos resultados das análises bioquímicas (proteínas e carboidratos, no caso) são insignificantes. Essa concentração varia conforme a espécie e o tipo de cultivo empregado.

Conforme Larcher (2000), uma característica marcante de um distúrbio no metabolismo das proteínas é a mudança nas proporções dos aminoácidos.

A seguir podemos observar que os níveis de aminoácidos solúveis totais (Figura 10) entre os tratamentos T1 (controle) e T3, não sofreu alteração, sendo estatisticamente iguais, portanto pode-se indicar que não houve alteração no metabolismo de proteínas para esses tratamentos.

Fica indicado que o tratamento que teve o menor acúmulo de proteínas solúveis totais foi o T5, o qual recebeu o menor suprimento em $\mathrm{N}\left(25 \mathrm{mmol}^{-L^{-1}}\right.$ de $\mathrm{N}$ total). Isso vem concordar com diversos autores já citados que observam que o $\mathrm{N}$ tem como uma das principais funções a formação de compostos primários básicos, como as proteínas. Segundo a idéia de Larcher (2000), neste tratamento pode ter havido uma mudança no metabolismo protéico, pois houve alto acúmulo de aminoácidos.

\subsection{Eletroforese de Proteínas Solúveis Totais em Gel de Poliacrilamida}

Os métodos de eletroforese são largamente utilizados na pesquisa com proteínas, quando se pretende determinar, por exemplo, a pureza das amostras utilizadas ou a massa molecular das proteínas presentes nas amostras. A técnica de eletroforese em gel de poliacrilamida (SDS-PAGE) baseia-se na migração de 
corrente elétrica através do polímero formado pela acrilamida no gel, o que resulta na separação das proteínas presentes na amostra em bandas protéicas, de acordo com o seu peso molecular (Copeland, 1994). A Figura 8 mostra a expressão de bandas de proteínas solúveis totais obtidas através da técnica de eletroforese em gel de poliacrilamida.

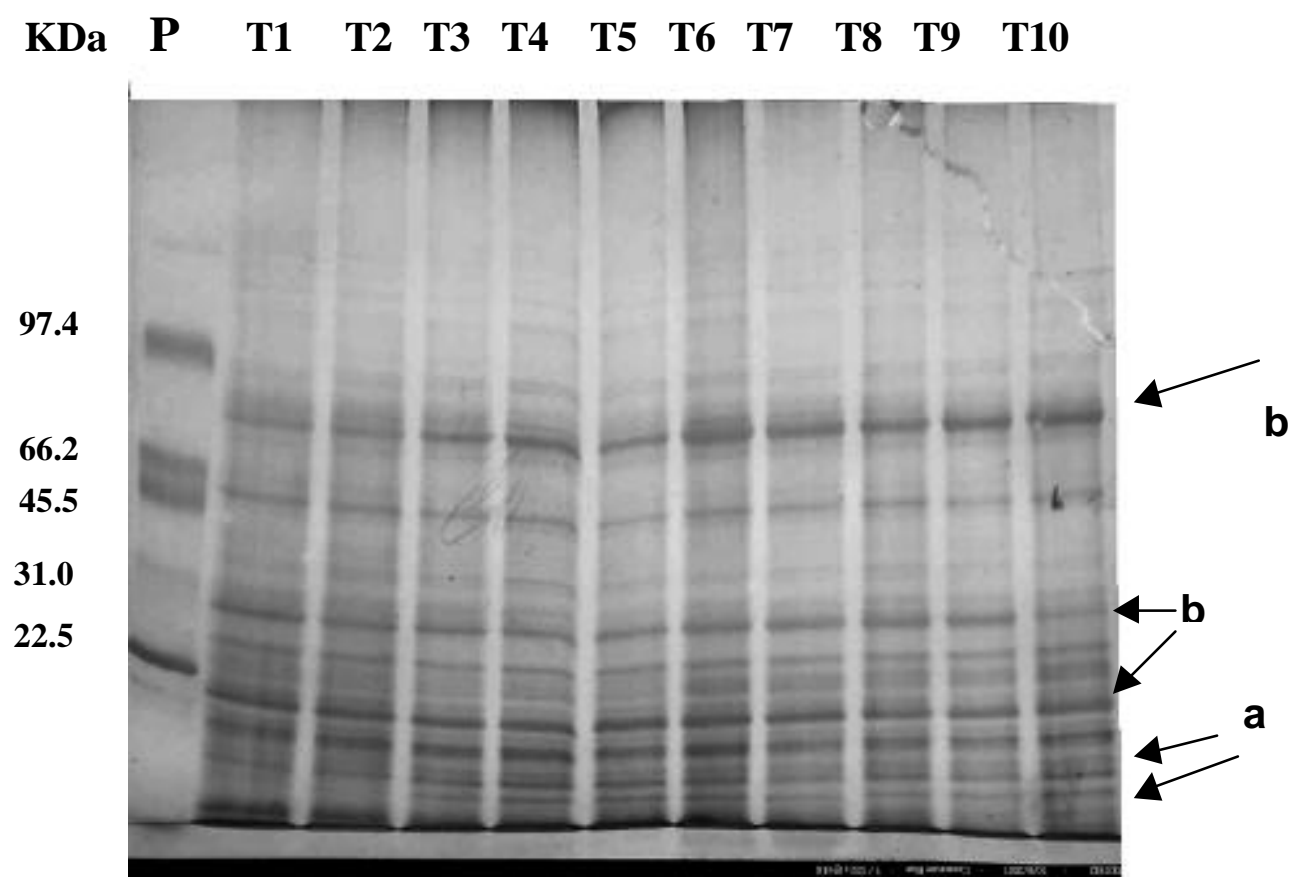

Figura 8 - Bandas protéicas observadas em explantes de Cryptomeria japonica D. Don. "elegans" após 90 dias de cultivo 'in vitro' sob os tratamentos com diferentes concentrações de $\mathrm{NO}_{3}{ }^{-}$e $\mathrm{NH}_{4}{ }^{+}$, indicados por $\mathrm{Tx}$ (Tabela 1). $\mathrm{O}$ padrão de proteínas utilizado está representado pela letra $\mathbf{P}$ e os valores numéricos contidos na figura representam os pesos moleculares das proteínas constituintes do padrão, em $\mathrm{KDa}$. As setas indicam: (a) expressão de bandas protéicas que não foi observada no controle e (b) diferença na intensidade de expressão das bandas quando comparadas ao controle. 
Pela análise dos resultados obtidos através do gel, observou-se algumas diferenças de expressão de bandas protéicas e de intensidade de expressão em comparação ao controle. Foi observado que o peso molecular das proteínas expressas em bandas variou entre 54 e 22kDa, consideradas proteínas de baixo peso molecular.

O T10 foi o tratamento que mais exibiu bandas protéicas e um dos tratamentos com maior síntese de proteínas solúveis totais, sendo possível, neste caso uma relação entre a quantificação de proteínas e a expressão de bandas. Outros tratamentos, como o T4, T5, T6 e T8 também exibiram síntese de bandas diferenciadas do controle, sobretudo bandas com pesos moleculares entre $31 \mathrm{e}$ $22 \mathrm{kDa}$.

O maior acúmulo de proteínas em T10 pode estar associado à ausência de amônio no meio de cultura e também ao fornecimento de nitrato em menor concentração (26mmol.. $\left.{ }^{-1}\right)$, pois, conforme Adams et al. (1982), Vollbrecht et al. (1989) e Khamis et al. (1990), sob menores fornecimentos de nitrato, a sua utilização pelas plantas em compostos básicos é maior que seu acúmulo no vacúolo, sobretudo na ausência de amônio.

\subsection{Conteúdo de Aminoácidos Solúveis Totais}

Na Figura 9, tem-se a curva analítica de calibração de leucina, utilizada como padrão para a quantificação de aminoácidos solúveis totais, a qual foi considerada adequada $\left(R^{2}=0,99\right)$ para a leitura das amostras retiradas dos diferentes tratamentos aplicados. 


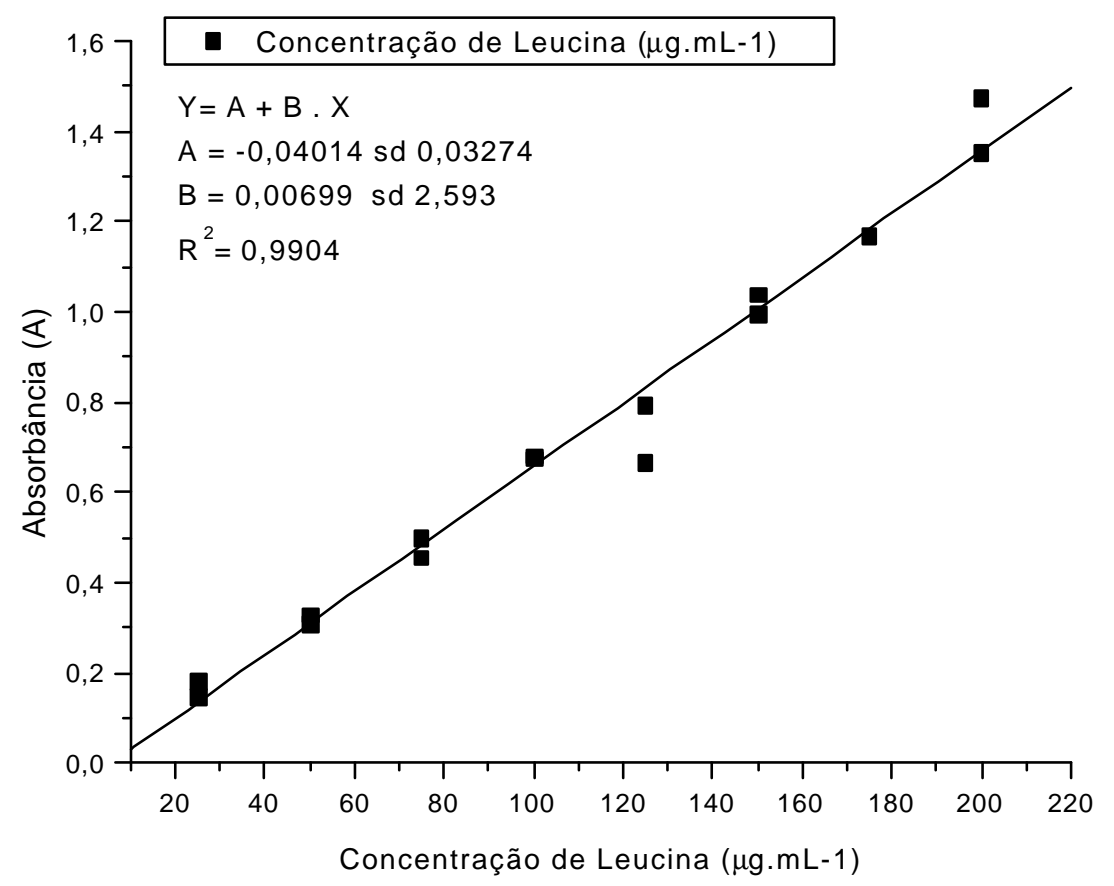

Figura 9 - Curva Analítica de calibração para Leucina.

Os conteúdos de aminoácidos solúveis totais encontrados nas amostras de Cryptomeria japonica D. Don "elegans" submetidas às diferentes concentrações de nitrato e amônio (Tabela 1), podem ser visualizados na Figura 10. 


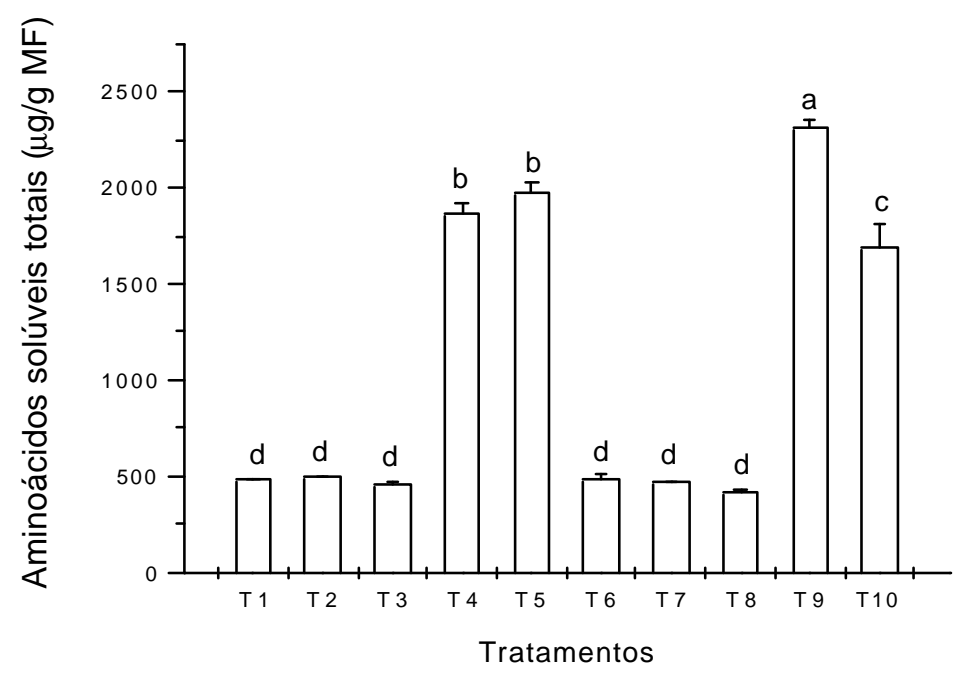

Figura 10 - Teores de aminoácidos solúveis totais quantificados nos explantes de Cryptomeria japonica D. Don. ao final de 90 dias de cultivo 'in vitro', sob as diferentes concentrações de $\mathrm{NO}_{3}{ }^{-}$e $\mathrm{NH}_{4}{ }^{+}$propostas (Tabela 1). As barras que exibem as mesmas letras referem-se aos tratamentos que não diferiram significativamente entre si, segundo o Teste de Tukey, para $p<0,05$.

O maior acúmulo de aminoácidos ocorreu no tratamento T8 $\left(28,5 \mathrm{mmol} . \mathrm{L}^{-1}\right.$ de nitrato $+2,5 \mathrm{mmol} . \mathrm{L}^{-1}$ de amônio $=31 \mathrm{mmol} . \mathrm{L}^{-1}$ de $\mathrm{N}$ total $)$, que exibe um teor de $\mathrm{N}$ total aproximadamente $50 \%$ menor que o controle ( $\mathrm{T} 1=\mathrm{MS}$ ). Os tratamentos T4 $\left(25 \mathrm{mmol} . \mathrm{L}^{-1}\right.$ de nitrato $+5 \mathrm{mmol} \cdot \mathrm{L}^{-1}$ de amônio $=30 \mathrm{mmol} . \mathrm{L}^{-1}$ $\mathrm{N}$ total) e T5 (22,5mmol. $\mathrm{L}^{-1}$ de nitrato $+2,5 \mathrm{mmol} . \mathrm{L}^{-1}$ de amônio $=25 \mathrm{mmol} . \mathrm{L}^{-1}$ de $\mathrm{N}$ total) exibiram o segundo maior teor, o que indica que as concentrações de $\mathrm{N}$ total entre 25 e $31 \mathrm{mmol}^{-1} \mathrm{~L}^{-1}$ foram mais benéficas ao acúmulo de aminoácidos solúveis totais. Estes tratamentos também estão entre os tratamentos que mais exibiram incremento em massa vegetal seca, assim como maiores TCR e síntese de proteínas solúveis totais, possibilitando, assim, indicar-se uma 
relação positiva entre essas variáveis e os teores de nitrato e amônio fornecidos aos explantes.

Hetch et al. (1990) verificaram que o teor de aminoácidos encontrado em cotilédones de plantas de mostarda foi maior quando o suprimento em $\mathrm{N}$ foi composto de nitrato de amônio. Em tratamentos onde a fonte de $\mathrm{N}$ foi exclusivamente nitrato ou amônio, os níveis foram menores. Os resultados foram considerados como uma indicação de que, na presença de determinadas concentrações de $\mathrm{NH}_{4} \mathrm{NO}_{3}$, a assimilação de amônio nos aminoácidos é estimulada. As quantificações de $\mathrm{N}$ total e de níveis de absorção de $\mathrm{N}$ indicaram que a incorporação de $\mathrm{N}$ inorgânico em compostos orgânicos foi fortemente influenciada pelas 2 formas de $\mathrm{N}$ fornecidas simultaneamente. Já 0 acúmulo de amônio é suprimido pela presença do nitrato, pois este induz a síntese de enzimas que atuam na incorporação do amônio em aminoácidos, fato que pode ter ocorrido em T4, T5 e T8. Esses tratamentos podem ter exibido concentrações de nitrato e amônio mais adequadas ao desenvolvimento da espécie, já que o nível de $\mathrm{N}$ exigido para um crescimento adequado varia conforme a espécie.

Caso os explantes tivessem exibido baixa TCR, tendo, assim seu crescimento e desenvolvimento influenciados negativamente pelo baixo fornecimento de N, poderia-se considerar a hipótese de síntese de aminoácidos relacionada a um possível estresse por carência nutricional (Larcher, 2000; Khamis et al. 1990). Porém, pelos dados de TCR, incremento em massa vegetal seca e ausência de sintomas de deficiência nutricional, essa hipótese não foi considerada.

O controle ( $\mathrm{T} 1=\mathrm{MS})$ foi o que exibiu menor acúmulo de aminoácidos entre os tratamentos analisados, juntamente com os outros tratamentos que continham as maiores concentrações de nitrogênio total, nitrato e amônio. 


\subsection{Conteúdo de Carboidratos não-estruturais Totais}

A Figura 11 mostra a curva analítica de calibração para a quantificação do teor de carboidratos não-estruturais totais no padrão utilizado, sendo esta, considerada adequada $\left(R^{2}=0,99\right)$ para a leitura das amostras de material vegetal cultivadas sob os diferentes tratamentos analisados.

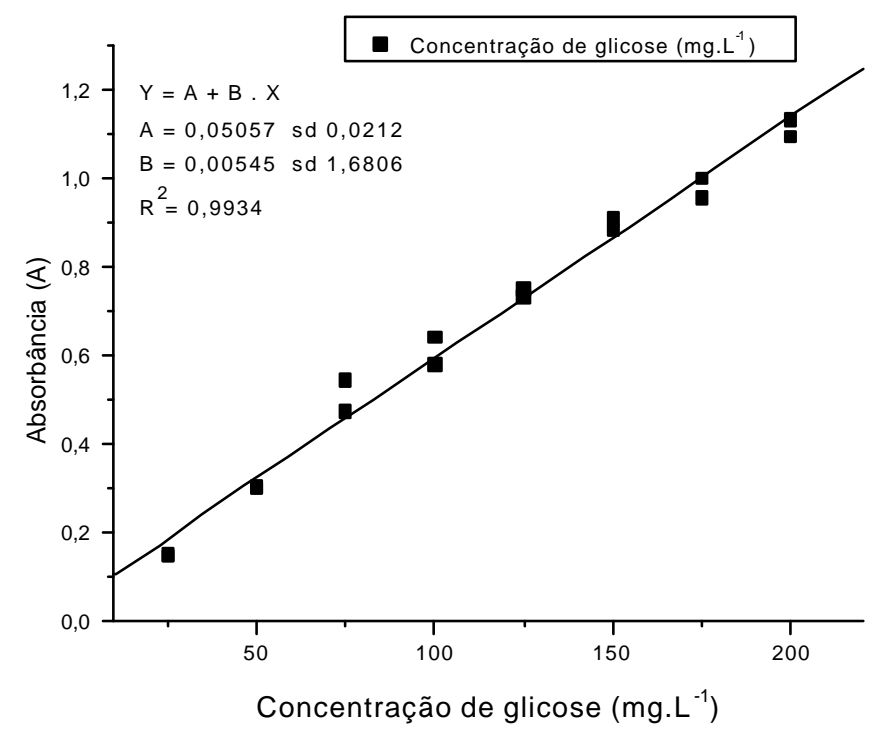

Figura 11 - Curva Analítica de calibração para Glicose.

A Figura 12 mostra o gráfico obtido pela análise quantitativa dos carboidratos não estruturais totais dos tratamentos utilizados. 


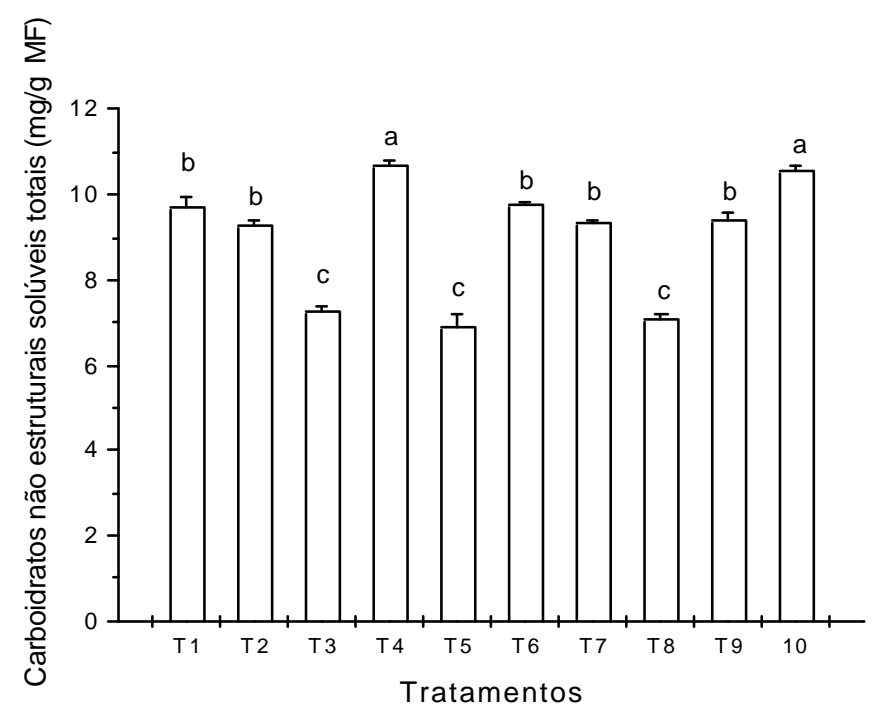

Figura 12 - Conteúdos de carboidratos não-estruturais solúveis totais quantificados em explantes de Cryptomeria japonica D. Don. "elegans" após 90 dias de cultivo 'in vitro' sob diferentes concentrações de $\mathrm{NO}_{3}{ }^{-}$e $\mathrm{NH}_{4}{ }^{+}$(Tabela 1). As barras com as mesmas letras referem-se aos tratamentos que não apontam diferenças significativas quanto ao Teste de Tukey, para $p<0,05$.

Sob baixas concentrações de nitrato e ausência de amônio, geralmente ocorre acúmulo de amido nos tecidos vegetais, fazendo aumentar a taxa de carboidratos mensurada (Khamis et al., 1990).

Já Amâncio et al. (1993) indicam que quando amônio é fornecido no meio de cultivo, há diminuição nos níveis de carboidratos sintetizados. Porém, espécies diferentes exibem tendências diferentes quanto a esses fatos.

Os metabolismos do nitrogênio e do carbono consomem a maior parte das reservas energéticas nos organismos fotossintéticos Huppe et al, 1994). Sob suprimentos limitantes de N, os carboidratos tendem a acumular-se e o nível de aminoácidos cai, ao passo que altos suprimentos de $\mathrm{N}$ podem 
induzir a degradação do amido pela deficiência no fluxo de $\mathrm{CO}_{2}$ aos carboidratos (Alhama et al., 1998). Resultados semelhantes aos dados da literatura foram encontrados em T4 e T10 (Figura 12).

O teor de amido é apontado como um indicador sensitivo das reservas de carboidratos das árvores, sendo reconhecido como o componente de maior armazenamento de carbono em muitas espécies de coníferas, ressaltando que os outros açúcares também estão presentes em tecidos vegetais analisados. O fluxo de carbono dentro da sacarose e do amido aumenta ou diminui em resposta ao suprimento em $\mathrm{N}$, sendo que a resposta pode variar segundo a espécie cultivada (Thompson et al, 1987; Weber et al., 1997).

A energia suprida pelos carboidratos é usada para a formação futura de raízes e também de brotações. Quando culturas de Pinus radiata diferenciadas para a formação de gemas foram comparadas com culturas não diferenciadas, ficou estabelecido que o acúmulo de alguns precursores (glucose e acetato) foram preferencialmente incorporados em tecidos diferenciados, demonstrando que houve intensificação do metabolismo, associando o metabolismo à diferenciação (Thompson et al.,1987).

Tappia et al. (1996) sugerem que a disponibilidade dos esqueletos de carbono limita a taxa de assimilação de amônio. É geralmente aceito que as vias de carbono e nitrogênio competem pelos esqueletos e carbono e pela energia.

Analisando o gráfico obtido (Figura 12), observa-se que o T4 e o T10 foram os que mais acumularam reservas e também dois dos tratamentos que mais exibiram formação de calos e gemas, o que vem concordar com Thompson et al (1987).

Pode-se também, analisando as afirmações de Tappia et al. (1996) indicar que este suprimento em $\mathrm{N}$, apesar de menor que o suprimento encontrado no MS não foi um fator limitante ao crescimento dos explantes em 
T4 e T10. Verificou-se ainda, que os tratamentosT4 e T8 apresentaram um nível de carboidratos menor que o controle, porém pelos índices de TCR, massa seca acumulada e padrões bioquímicos não houve limitação do desenvolvimento dos explantes.

Portanto, podemos indicar que, os tratamentos T4, T5, T8 e T10 proporcionaram melhor desenvolvimento 'in vitro' aos explantes de Cryptomeria japonica D. Don. "elegans" no período analisado.

\subsection{Experimento com Reguladores Vegetais}

\subsubsection{Produção de Brotações}

Os resultados de produção de brotações obtidos durante 0 experimento com reguladores vegetais, utilizando os meios de cultura contendo diferentes concentrações de nitrato e amônio, denominados T1 $\left(40 \mathrm{mmol}^{-\mathrm{L}^{-1}}\right.$ de $\mathrm{NO}_{3}{ }^{-}+20 \mathrm{mmol}^{-L^{-1}}$ de $\left.\mathrm{NH}_{4}{ }^{+}\right) ; \mathrm{T} 4\left(25 \mathrm{mmol}^{-L^{-1}}\right.$ de $\mathrm{NO}_{3}{ }^{-}+5 \mathrm{mmol}^{-\mathrm{L}^{-1}}$ de $\left.\mathrm{NH}_{4}{ }^{+}\right) ; \mathrm{T} 5$ $\left(22,5 \mathrm{mmol} . \mathrm{L}^{-1}\right.$ de $\mathrm{NO}_{3}^{-}+2,5 \mathrm{mmol}^{-} \mathrm{L}^{-1}$ de $\left.\mathrm{NH}_{4}{ }^{+}\right)$; T8 $\left(31 \mathrm{mmol}^{-1}{ }^{-1}\right.$ de $\mathrm{NO}_{3}^{-}+$ $5 \mathrm{mmol} . \mathrm{L}^{-1}$ de $\left.\mathrm{NH}_{4}{ }^{+}\right)$e T10 (26mmol. $\mathrm{L}^{-1}$ de $\left.\mathrm{NO}_{3}{ }^{-}\right)$, os quais foram suplementados pelas concentrações de ANA e BAP descritas na Tabela 2, mostraram que, com exceção do material vegetal cultivado sob T8, os explantes suplementados com maiores concentrações de BAP durante o experimento com reguladores vegetais exibiram maiores taxas de formação de brotações, porém, a presença de ANA foi necessária para os melhores resultados em termos de produção de brotações.

Já nos tratamentos suplementados por maiores concentrações de ANA, a formação de brotações foi menor. Porém tais brotações exibiram uma altura média maior. 
Essas indicações encontram-se em concordância com vários autores, como Ferri (1979); Krikorian et al. (1988) e Salisbury et al. (1992), os quais destacam os principais papéis das auxinas e citocininas no crescimento e desenvolvimento vegetal, sendo a citocinina responsável pelo estímulo ao processo de divisão celular, ocasionando assim, a multiplicação do material cultivado pelo aparecimento de novas brotações. A auxina é mais relacionada à formação de massas celulares sem diferenciação (calos), à formação de raízes e ao alongamento das células.

A Figura 13 mostra a produção média de brotações por explante e a altura média destas brotações $(\mathrm{mm})$ durante os 3 subcultivos analisados (90 dias). 


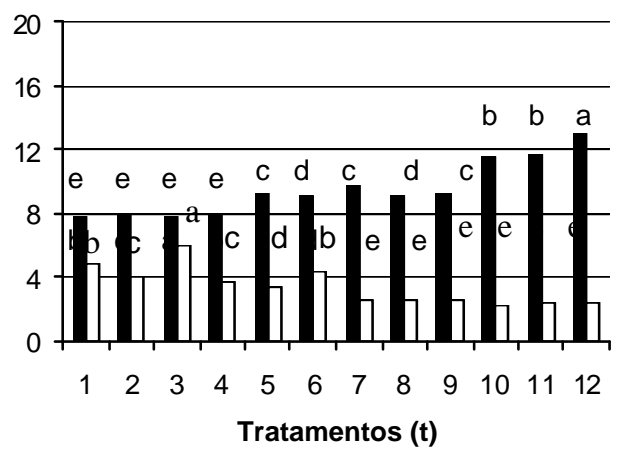

T1

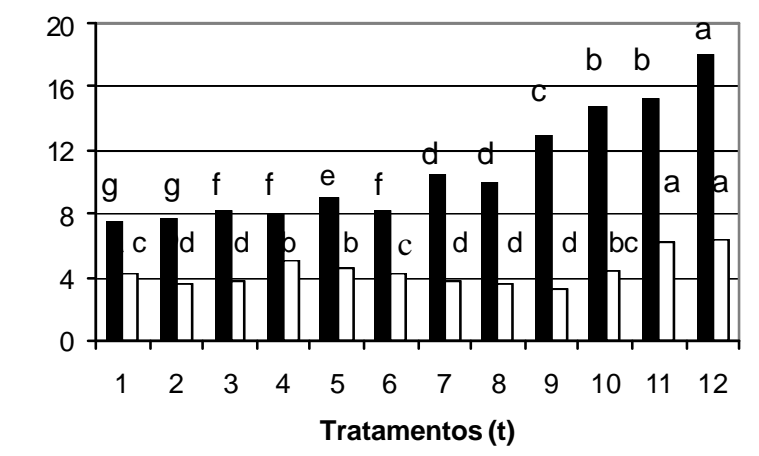

T5

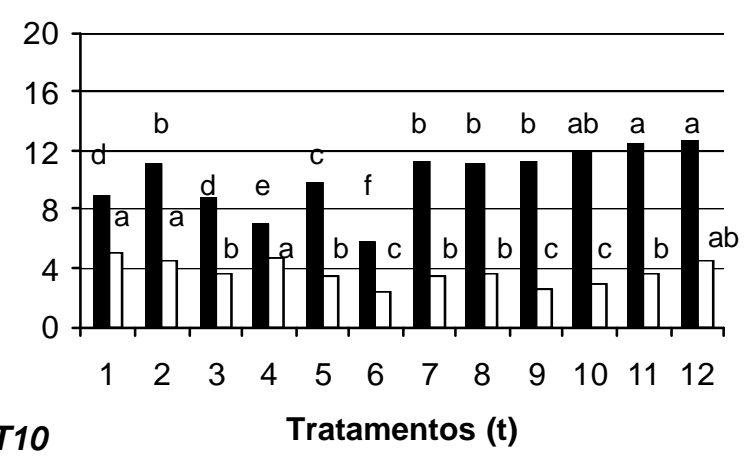

Número médio de brotações/explante Altura média de brotações/explante ( $\mathrm{mm}$ )

Figura 13 - Número médio de brotações formadas por explante e altura média $(\mathrm{mm})$ das brotações produzidas em 3 subcultivos (90 dias). Resultados obtidos a partir de explantes de Cryptomeria japonica D. Don. "elegans" cultivados 'in vitro' sob T1, T4, T5, T8 e T10, sob diferentes relações entre ANA e BAP (Tabela 2). 
De um modo geral, os explantes cultivados no meio de cultura MS (controle=T1) exibiram menor formação de calos e brotações quando comparados aos explantes mantidos sob os demais tratamentos, mostrando que, em concordância com os resultados obtidos durante o experimento com diferentes concentrações de nitrato e amônio, os maiores teores de $\mathrm{N}$ não foram os mais satisfatórios ao desenvolvimento 'in vitro' dos explantes de Cryptomeria japonica D. Don. "elegans".

Entretanto, os explantes mantidos sob concentrações de $25 \mathrm{mmol} . \mathrm{L}^{-1}$ de nitrato + $5 \mathrm{mmol} . \mathrm{L}^{-1}$ de amônio e 22,5mmol. $\mathrm{L}^{-1}$ de nitrato $+2,5 \mathrm{mmol} . \mathrm{L}^{-1}$ de amônio (Figura 13 , T4 e T5) exibiram maior produção de brotações em relação ao controle (T1=MS) e aos demais tratamentos, sobretudo nos tratamentos (t) com predomínio de BAP (t9 a t12), sendo a maior produção de brotações/explante (16 em T4 e 18 em T5) observada quando se utilizou 2mg. $\mathrm{L}^{-1}$ de BAP + $1 \mathrm{mg} \cdot \mathrm{L}^{-1}$ de ANA (t12). Em termos gerais, a altura média das brotações formadas foi superior em T4 e em T5 quando comparados ao controle, mesmo sob os tratamentos onde houve predomínio de citocinina ( $\mathrm{t} 9, \mathrm{t} 10, \mathrm{t} 11$ e $\mathrm{t} 12)$.

Esses resultados vêm auxiliar na indicação de que as composições de meio de cultura com concentrações de nitrato e amônio menores que as encontradas no meio MS foram mais satisfatórias ao desenvolvimento dos explantes de C. japonica cultivados 'in vitro', já que alguns tratamentos como o T4 e T5 já exibiram resultados superiores quanto à TCR, incremento em massa seca e nas análises bioquímicas, salientando que as maiores taxas de produção de brotações foram apresentadas em T5, suplementado por 2,0mg. $\mathrm{L}^{-1}$ de BAP e $1,0 \mathrm{mg} \cdot \mathrm{L}^{-1}$ de NAA. 


\section{CONCLUSÕES}

Com base nos objetivos propostos, nas hipóteses estabelecidas e nos resultados obtidos, foi possível indicar que, as diferentes concentrações de nitrato e amônio influenciaram o crescimento (TCR), o incremento em massa vegetal seca dos explantes cultivados 'in vitro', assim como os conteúdos de proteínas, aminoácidos, carboidratos e a expressão de bandas protéicas em eletroforese em gel de poliacrilamida'.

Quando se omitiu o amônio do meio de cultura, foram obtidas respostas consideráveis em termos de TCR, incremento em massa seca e nas análises bioquímicas, porém, a produção de brotações foi menor que a encontrada em outros tratamentos. Isso indica que 0 amônio, presente em baixas concentrações foi favorável ao desenvolvimento 'in vitro' dos explantes de brotações de Cryptomeria japonica D. Don. "elegans" durante o período analisado.

Através do experimento com diferentes concentrações de ANA e BAP, aplicadas aos tratamentos selecionados durante o experimento com diferentes concentrações de amônio e nitrato, foi possível observar o efeito dos reguladores vegetais sobre a produção de brotações, aliando seus efeitos às concentrações de $\mathrm{N}$ fornecidas aos explantes.

Portanto, podemos considerar que os explantes cultivados 'in vitro' exibiram melhor desenvolvimento quando cultivados sob $22,5 \mathrm{mmol}^{-1} \mathrm{~L}^{-1}$ de nitrato $+2,5 \mathrm{mmol} . \mathrm{L}^{-1}$ de amônio e $25,0 \mathrm{mmol} . \mathrm{L}^{-1}$ de nitrato $+5,0 \mathrm{mmol} . \mathrm{L}^{-1} \mathrm{de}$ amônio, suplementados por 2,0mg. $\mathrm{L}^{-1}$ de BAP $+1,0 \mathrm{mg} \cdot \mathrm{L}^{-1}$ de ANA. 
Estudos posteriores poderiam auxiliar na definição de apenas uma concentração de nitrato e amônio, dado ao fato de que em T5 houve melhor índice de produção de brotações, porém em T4 os níveis dos parâmetros bioquímicos foram mais satisfatórios. Ou seja, talvez o conteúdo de carboidratos (maior em T4) se tornasse um fator importante no processo de alongamento e enraizamento das brotações formadas. Por esse fato, optou-se por determinar tanto T4 como T5 como adequados. 


\section{REFERÊNCIAS BIBLIOGRÁFICAS}

ADAMS, M. A.; ATTIWILL, P. M. Nitrate reductase activity and growth response of forest species to ammonium and nitrate sources of nitrogen. Plant and Soil, v. 66, p. 373-381, 1982.

ALFENAS, A. C.; PETERS, I.; BRUNE, W.; PASSADOR, G. C. Eletroforese de proteínas de isoenzimas de fungos e essências florestais. Viçosa: SIF, 1991. $241 \mathrm{p}$.

ALHAMA, J.; LOPES-RUIZ, A.; DIEZ, J.; GARCIA-FERNANDEZ, J. M. Nitrogen availability on intracellular amino acids and ammonium pools in the green alga Monoraphidium braunii. Journal of Plant Physiology, v. 153, p. 529-533, 1998.

AMÂNCIO, S.; DIOGO, E.; SANTOS, H. Effects of source of inorganic nitrogen on $\mathrm{C}$ and $\mathrm{N}$ interaction in maize callus tissue: phosphoenolpyruvate carboxylase activity, cytosolic $\mathrm{pH}$ and ${ }^{15} \mathrm{~N}$ amino acids. Physiologia Plantarum, v. 89, p. 618-625, 1993.

BAJAJ, Y. P. S. Biotechnology in agriculture and forestry 5: trees II. Berlin: Springer-Verlag, 1989. v. 5, 480p.

BRADFORD, M. M. A rapid and sensitive method for the quantitation of microgram quantities of protein utilizing the principle of protein-dye binding. Analytical Biochemistry, v. 71, n. 1, p. 248-254, 1976. 
BRUM, G.; McKANE, L.; KARP, G. Biology: exploring life. 2.ed. New York: John Wiley, 1994. 1030p.

CÁNOVAS, F. M.; CANTÓN, F. R.; GUTIÉRREZ, A. G.; GALLARDO, F.; CRESPILLO, R. Molecular physiology of glutamine and glutamate biosynthesis in developing seedlings of conifers. Physiologia Plantarum, v. 103, p. 287294, 1998.

CAPUANA, M.; GIANNINI, R. Micropropagation of young and adult plants of cypress (Cupressus sempervirens L.). Journal of Horticultural Science, v.72, n.3, p. 453-460, 1997.

CHANG, S.; SEN, S.; McKINLEY, C. R.; AIMERS-HALLIDAY, J.; NEWTON, R. J. Clonal propagation of Virginia Pine (Pinus virginiana Mill.) by organogenesis. Plant Cell Reports, v. 10, p. 131-134, 1991.

COPELAND, R. A. Methods for protein analysis: a practical guide for laboratory protocols. New York: Chapman and Hall, 1994. 228p.

CUMMING, J. R. Nitrogen source effects on Al toxicity in nonmycorrhizal and mycorrhizal pitch pine (Pinus rigida) seedlings. II. Nitrate reduction and $\mathrm{NO}_{3}{ }^{-}$ uptake. Canadian Journal of Botany, v. 68, p. 2653-2659, 1990.

DENOSO, I. 'In Vitro' propagation of some conifers. Acta Horticulturae, n. 289, p. 103-104, 1991.

DROUAL, A. M.; HAMDI, S.; CRECHE, J.; KEVERS, C.; RIDEAU, M. Autonomy to plant growth regulators and gene expression in Periwinkle cultures 'in vitro'. Journal of Plant Physiology, v. 153, p. 623-630, 1998.

ELKONIN, L. A.; PAKHOMOVA, N. V. Influence of nitrogen and phosphorus on induction embryogenic callus of sorghum. Plant Cell, Tissue and Organ Culture, v. 61, p. 115-123, 2000.

EVERS, P. W. Micropropagation of forest trees through tissue culture. Wageningen: Pudoc, 1988. 84p.

FERRI, M. G. Fisiologia vegetal. São Paulo: EPU; EDUSP, 1979. v. 2, 392p. 
GESSLER, A.; SCHNEIDER, S.; VON SENGBUSCH. D.; WEBER, P.; HANEMANN, U.; HUBER, C.; ROTHE, A.; KREUTZER, K.; RENNENBERG, $\mathrm{H}$. Field and laboratory experiments on net uptake of Nitrate and Ammonium by the roots of Spruce (Picea abies) and Beech (Fagus sylvatica) trees. New Phytologist, v. 138, p. 275-285, 1998.

GEORGE, E. F. Plant propagation by tissue culture: handbook and commercial laboratories. Eversley: Exegetics, 1984.700p.

GOLDFARB, B., ZAERR, J. B. Douglas-Fir [Pseudotsuga menziesii (Mirb.) Franco]. In: BAJAJ, Y. P. S. Biotechnology in agriculture and forestry 5: trees II. Berlin: Springer-Verlag, 1989. v. 5, cap.2, p. 526-548.

GONZÁLEZ, M. V.; REY, M.; TABAZA, R.; LA MALFA, S.; CUOZZO, L.; ANCORA, G. 'In vitro' adventitious shoot formation on cotyledons of Pinus pinea. HortScience, v. 33, n. 4, p. 479-750, 1998.

GROSSI, F. Adequação nutricional do meio de cultura para crescimento e desenvolvimento de gemas de Eucalyptus saligna Smith 'in vitro', Procedência Itatinga. Piracicaba, 1995, 125p. Dissertação (Mestrado) Escola Superior de Agricultura "Luiz de Queiroz", Universidade de São Paulo. GUPTA, P. K.; DURZAN, D. J. Shoot multiplication from mature trees of Douglasfir (Pseudotsuga menziesii) and Sugar Pine (Pinus lambertiana). Plant Cell Reports, v. 4, p. 177-179, 1985.

HARRY, I. S.; THORPE, T. A. Regeneeration of plantlets through organogenesis from mature embryos of jack pine. Plant Cell, Tissue and Organ Culture, v. 37, p. 159-164, 1994.

HECTH, U.; MOHR, H. Factors controlling nitrate and ammonium accumulation in mustard (Sinapsis alba) seedlings. Physiologia Plantarum, v. 78, p. 379387, 1990.

HEPLER, P. K.; WAYNE, R. O. Calcium and plant development. Annual Review of Plant Physiology, v. 36, p. 397-439, 1985. 
HUNT, R. Plant growth curves: the functional approach to plant growth analysis. London: Edward Arnold, 1982. 248p.

HUPPE, H. C.; TURPIN, D. H. Integrations of carbon and nitrogen metabolism in plants and algal cells. Plant Molecular Biology, v. 45, p. 577-607, 1994.

INGESTAD, T. Mineral nutriente requeriments of Pinus sylvestris and Picea abies seedlings. Physiologia Plantarum, v. 45, p. 373-380,1979.

INGESTAD, T.; AGREN, G. I. Plant nutrition and growth: basic principles. Plant and Soil, v. 168/169, p. 15-20, 1995.

ISIKAWA, H. Cryptomeria (Cryptomeria japonica D. Don.). In: BAJAJ, Y. P. S. Biotechnology in agriculture and forestry 1: trees I. Berlin: SpringerVerlag, 1986. v. 1, cap. 4, p. 316-321.

ISIKAWA, H. 'In vitro' culture of Cryptomeria callus and organs. In: BONGA, J. M.; DURZAN, D. J. Cell and tissue culture in forestry. Boston: Martinus Nijhoff, 1987. v. 3, p. 109-113.

KHAMIS, S.; LAMAZE, T. Maximal biomass production can occur in corn (Zea mays) in the absence of $\mathrm{NO}_{3}^{-}$accumulation in either leaves or roots. Physiologia Plantarum, v. 78, p. 388-394, 1990.

KAUL, K.; HOFFMAN, S. A. Ammonium ion inhibition of Pinus strobus L. callus growth. Plant Science, v. 88, p. 169-173, 1993.

KRIKORIAN, A. D.; KELLY, K.; SMITH, D. L. Hormones in tissue culture and micropropagation. In: DAVIES, P. J. Plant hormones and their role in plant growth and development. Wageningen: Kluwer Academic 1988. cap. E-18, p. 593-613.

LARCHER, W. Ecofisiologia vegetal. São Carlos: RiMa Artes e Textos, 2000. $531 p$.

LAUKKANEN, H.; TIITTO, R. J.; HOHTOLA, A. Effect of different nitrogen nutrients on the viability, protein synthesis and tannin production of Scots pine callus. Physiologia Plantarum, v. 100, p. 982-988, 1997. 
LEE, J. S.; MULKEY, T. L.; EVANS, M. L. Inhibition of polar calcium movement and gravitropism in roots treated with auxin-transport inhibitors. Planta, v. 160, p. 536-543, 1984.

LITTLE, C. H. A. Promoting bud development in balsam fir Christmas trees with 6benzylaminopurine. Canadian Journal of Forest Research, v. 14, p. 447-451, 1984.

MALAVOLTA, E. Avaliação do estado nutricional das plantas: princípios e aplicações. Piracicaba: Potafós, 1997. 319p.

MARSCHNER, $H$. Mineral nutrition of higher plants. London: Academic Press, 1986. 674p.

MENGEL, K.; KIRKBY, E. A. Principles of plant nutrition. 4.ed. Bern: International Potash Institute, 1987.687p.

MILLARD, P. The accumulation and storage of nitrogen by herbaceous plants. Plant and Cell Environment, v. 11, p. 1-8, 1988.

MORTE, M. A.; HONRUBIA, M.; PIQUERAS, A. Micropropagation of Tetraclinis articulata (Vahl.) Masters (Cupressaceae). Plant Cell, Tissue and Organ Culture, v. 28, p. 231-233, 1992.

MURASHIGUE, T.; SKOOG, F. A revised medium for rapid growth and bioassays with tobacco tissue culture. Physiologia Plantarum, v. 15, p. 473-497, 1962.

PASSOS, L. P. Métodos analíticos e laboratoriais em fisiologia vegetal. Coronel Pacheco: EMBRAPA,CNPGL, 1996. 223p.

POCHET, B.; SCOMAN, V.; MESTDAGH, M. M.; MOREAU, B.; ANDRE, P. Influence of agar gel properties on the 'in vitro' micropropagation of different clones of Thuja plicata. Plant Cell Reports, v. 10, p. 406-409, 1991.

PORTER, J. R.; LAWLOR, D. W. Plant growth: interactions with nutrition and environment. Cambridge: University of Cambridge Press, 1991. 284p. 
RAVEN, P. H.; EVERT, R. F.; EICHHORN, S. E. Biologia vegetal. 5.ed. Rio de Janeiro: Editora Guanabara, 1996. 728p.

SAlisBURY, F. B.; ROSS, C. W. Plant physiology. 4.ed. San Farncisco: Wadsworth Publ., 1991. 682p.

SELBY, C.; HARVEY, B. M. R. The influence of the basal medium on the growth and morphogenesis of cultured stika spruce (Picea stichensis) tissues. Annals of Botany, v. 65, p. 395-407, 1990.

SLOCUM, R. D.; ROUX, S. J. Cellular and subcellular localization of calcium in gravistimulated coleoptiles and its possible significance in establishment of tropic curvature. Planta, v. 157, p. 481-192, 1983.

SPANOS, K. A.; PIRRIE, A.; WOODWARD, S. Micropropagation of Cupressus sempervirens L. and Chamaecyparis lawsoniana (A. Murr.) Par. Silvae Genetica, v. 46, n. 5, p. 291-295, 1997.

TAIZ, L.; ZEIGER, E. Plant physiology. 2.ed. Saunderland: Sinauer Associates, 1998. 792p.

TAPPIA, M. I.; OCHOA DE ALMEIDA, J. A. G.; LLAMA, M. J.; SERRA, J. L. Changes in intracellular amino acids and organic acids induced by nitrogen starvation and nitrate or ammonium resupply in the cyanobacterium Phormidium laminosum. Planta, v. 198, p. 526-531, 1996.

TEASDALE, R. D. Micronutrientes. In: BONGA, J. M.; DURZAN, D. J. Cell and tissue culture in forestry: general principles and biotechnology. Dordrecht: Martinus Nijhoff, 1987. v. 1, p. 17-49.

THOMPSON, M. R. Future options for the genetic improvement of conifers. Part II: Longer-term technologies. Irish Forestry, v. 50, n. 3, p. 108-122, 1993.

THOMPSON, M. R.; THORPE, T. A. Metabolic and non-metabolic roles of carbohydrates. In: BONGA, J. M.; DURZAN, D. J. Cell and tissue culture in forestry: general principles and biotechnology. Dordrecht: Martinus Nijhoff, 1987. v.1, cap. 6, p. 89-112. 
TORIBIO, M.; PARDOS, J. A. Scots pine (Pinus sylvestris L.). In: BAJAJ, Y. P. S. Biotechnology in agriculture and forestry 5: trees II. Berlin: SpringerVerlag, 1989. v. 5, cap. 2, p. 479-506.

TREMBLAY, L.; TREMBLAY, F. M. Effects of gelling agents, ammonium nitrate, and light on the development of Picea mariana (Mill) B.S.P. (black spruce) and Picea rubens Sarg. (red spruce) somatic embryos. Plant Science, v. 77, p. 233-242, 1991.

TSAI, C. J.; SAUNDERS, J. W. Evaluation of sole nitrogen sources for shoot and leaf disc cultures of sugarbeet. Plant Cell, Tissue and Organ Culture, v. 59, p. 47-56, 1999.

TUSKAN, G. A.; SARGENT, W. A.; RENSEMA, T.; WALLA, J. A. Influence of plant growth regulators, basal media and carbohydrate levels on the 'in vitro' development of Pinus ponderosa (Dougl. ex Law.) cotyledon explants. Plant Cell, Tissue and Organ Culture, v. 20, p. 47-52, 1990.

VAN DEN DRIESSCHE, R. Mineral nutrition of conifer seedlings. Boca Raton: CRC Press, 1991. 274p.

VIEIRA, E. C.; GAZZINELLI, G.; MARES-GUIA, M. Bioquímica celular e biologia molecular. 2.ed. São Paulo: Atheneu, 1991. 360p.

VELIKY, I. A.; ROSE, D. Nitrate and ammonium as nitrogen nutrients for plant cell cultures. Canadian Journal of Botany, v. 51, p. 1837-1844, 1973.

VOLLBRECHT, P.; KLEIN, E.; KASEMIR, H. Different effects of supplied ammonium on glutamine synthetase activity in mustard (Sinapsis alba) and pine (Pinus sylvestris). Physiologia Plantarum, v. 77, p. 129-135, 1989.

WEBER, H.; GOLOMBECK, S.; HEIM, U.; BORISJUK, L.; PANITZ, R.; MANTEUFFEL, R.; WOBUS, U. Integration of carbohydrate and nitrogen metabolism during legume seed development: implications for storage product synthesis. Journal of Plant Physiology, v. 152, n. 6, p. 641-648, 1998. 
YEMM, E. W.; WILLIS, A. J. The estimation of carbohydrates in plant extracts by anthrone. The Biochemical Journal, v.57, n.3, p.508-515, 1954. 


\section{APÊNDICE 1}

PROTEÍNAS SOLÚVEIS TOTAIS (Bradford, 1976)

\section{a. Solução de Extração de Proteínas Solúveis Totais:}

4,0 mL de Tampão TRIS-HCl pH 6.8; 1,6 mL de mercaptaetanol; 6,4 mL de solução de SDS a 10\% (P/V); 6,4 mL de solução de Glicerol a 50\% (V/V); 3,2 mL de DMSO; 1,0-3,0g de PVP; 10,4 mL de água destilada deionizada.

\section{b. Solução Estoque de Coomassie Brilliant Blue G 250:} 100mg de Commassie Brilliant Blue em 50mL de etanol.

Agitar a solução vigorosamente e adicionar lentamente $100 \mathrm{~mL}$ de ácido fosfórico $\left(\mathrm{H}_{3} \mathrm{PO}_{4}\right)$. Completar o volume para $1 \mathrm{~L}$ com água destilada deionizada e filtrar em papel Whatman $n^{\circ} 1$.

c. Solução estoque de albumina bovina (BSA):

$0,5 \mathrm{mg}$ de $\mathrm{BSA} / \mathrm{mL}$ de $\mathrm{NaCl} 0,5 \mathrm{M}$. 


\section{APÊNDICE 2}

\section{ELETROFORESE EM GEL DE POLIACRILAMIDA (Alfenas et al., 1991)}

\section{a. Preparo do Gel}

\section{a.1 Gel de Corrida a $10 \%$}

$7 \mathrm{~mL}$ de solução de acrilamida a 10\%; $10 \mathrm{~mL}$ de Tampão Tris $\mathrm{pH} 8,8 ; 2,5 \mathrm{~mL}$ de água destilada deionizada; 15ìL de TEMED; 330ìL de solução de persulfato de amônio a $10 \%$

\section{a.2 Gel Espaçador ou de Separação a 3\%}

$1 \mathrm{~mL}$ de solução de acrilamida a 10\%; 3,3mL de Tampão Tris pH 6,8; $2 \mathrm{~mL}$ de água destilada deionizada; 15ìL de TEMED; 200ìL de solução de persulfato de amônio a $10 \%$.

\section{b. Tampão de Corrida do Gel (concentrado)}

57,6g de Glicina; $12,6 \mathrm{~g}$ de Trisma-Base

Completar o volume para $1 \mathrm{~L}$ com água destilada deionizada. Conservar em geladeira. Para a utilização do tampão na cuba de corrida de eletroforese diluir 4 vezes o tampão de corrida em água destilada deionizada e acrescentar $10 \%$ do volume total da solução de SDS a 10\% (P/V). 


\section{c. Procedimento para coloração do Gel com Prata}

\section{c.1 Solução Fixadora}

$400 \mathrm{~mL}$ de etanol; $100 \mathrm{~mL}$ de ácido acético glacial; $500 \mathrm{~mL}$ de água destilada deionizada. Aplicar a solução sobre o gel por, no mínimo, 12 horas.

\section{c.2 Solução Incubadora}

$17 \mathrm{~g}$ de acetato de sódio $3 . \mathrm{H}_{2} \mathrm{O} ; 75 \mathrm{~mL}$ de etanol; $1 \mathrm{~g}$ de tiossulfato de sódio; $1,3 \mathrm{~mL}$ de solução de glutaraldeído a $25 \%$. Completar o volume para $250 \mathrm{~mL}$ com água destilada deionizada.

Tempo de aplicação sobre o gel: 15 minutos.

c.3 Lavar o gel em água destilada deionizada por 3 vezes, sendo cada lavagem realizada por um período de 10 minutos.

\section{c.4 Solução de Nitrato de Prata}

$0,25 \mathrm{~g}$ de nitrato de prata; $50 \mathrm{il}$ de formaldeído. Completar o volume para $250 \mathrm{~mL}$ com água destilada deionizada.

Tempo de aplicação sobre o gel: 20 minutos.

\section{c.5 Solução Reveladora}

$6,25 \mathrm{~g}$ de carbonato de sódio; $25 i ̀ \mathrm{~L}$ de formaldeído. Completar o volume para $250 \mathrm{~mL}$ com água destilada deionizada.

Tempo de aplicação sobre o gel: até que apareçam as bandas protéicas.

\section{c.6 Solução "Stop"}

$3,65 \mathrm{~g}$ de sódio-EDTA. Dissolver e completar o volume para $250 \mathrm{~mL}$ com água destilada deionizada. Aplicar a solução sobre o gel por 10 minutos.

c.7 Lavagem do gel em água corrente por, no mínimo, 1 hora. 


\section{APÊNDICE 3}

\section{CARBOIDRATOS NÃO ESTRUTURAIS TOTAIS (Yenm \& Willis, 1954)}

\section{a. Reagente de Antrona:}

$45 \mathrm{~mL}$ de ácido sulfúrico concentrado em $5 \mathrm{~mL}$ de água destilada deionizada; $100 \mathrm{mg}$ de antrona. Resfriar a solução em temperatura ambiente e deixar em repouso por 30 minutos, agitando ocasionalmente para obter-se a clarificação da mesma. 


\section{APÊNDICE 4}

\section{AMINOÁCIDOS SOLÚVEIS TOTAIS (Passos, 1996)}

\section{a. Reagente de Ninidrina:}

$125 \mathrm{~mL}$ de tampão acetato $4 \mathrm{~N} \mathrm{pH} 5,5$ em $375 \mathrm{~mL}$ de éter monometílico de etilenoglicol, contendo $1 \mathrm{~g}$ de ninidrina e $150 \mathrm{mg}$ de hidrindantina.

\section{b. Reagente de Hidrindantina (estoque)}

$8 \mathrm{~g}$ de ninidrina em $200 \mathrm{~mL}$ de água destilada deionizada a $90^{\circ} \mathrm{C}$.

Em ato contínuo, dissolver $8 \mathrm{~g}$ de ácido ascórbico em $40 \mathrm{~mL}$ de água destilada deionizada, a $40^{\circ} \mathrm{C}$. Agitar a solução de ninidrina e, em seguida adiciona-la à solução de ácido ascórbico. A cristalização da hidrindantina se inicia imediatamente. Deixar o processo ocorrer por mais 30 minutos, resfriar a solução final em temperatura ambiente e filtrá-la.

\section{c. Tampão Acetato (estoque)}

$544 \mathrm{~g}$ de $\mathrm{NaOAc} .3 \mathrm{H}_{2} \mathrm{O} ; 400 \mathrm{~mL}$ de água destilada deionizada. Dissolver e adicionar $100 \mathrm{~mL}$ de ácido acético glacial, ajustar o pH da solução à 5,5 e completar o volume com água destilada deionizada para $1 \mathrm{~L}$.

\section{c. Reagente de Ninidrina:}

$125 \mathrm{~mL}$ de tampão acetato $4 \mathrm{~N} \mathrm{pH} 5,5$ em $375 \mathrm{~mL}$ de éter monometílico de etilenoglicol, contendo $1 \mathrm{~g}$ de ninidrina e $150 \mathrm{mg}$ de hidrindantina. 